\title{
Padlina i sępy. Czy logion Q 17,37 jest biblijnym cytatem (illud dictum), przysłowiem (proverbium), czy znakiem (signum)? Analiza egzegetyczno-teologiczna
}

\author{
Carrion and Vultures. \\ Is the Logion Q 17:37 either a Biblical Quotation (illud dictum) or a Proverb \\ (proverbium) or a Sign (signum)? An Exegetical and Theological Study
}

\author{
ARNOLD ZAWADZKI \\ Sekcja Nauk Biblijnych, Katolicki Uniwersytet Lubelski Jana Pawła II \\ e-mail: zawadzki.a@icloud.com \\ ORCID: 0000-0002-7827-7881
}

\begin{abstract}
The article proposes a detailed syntactic and semantic analysis of Matt 24:28 and Luke 17:37c for the purpose of hypothetical reconstructing of the original Semitic (Hebrew and Aramaic) form of the logion Q 17:37. Then it is offered the comparison between the three different hermeneutic opportunities in its understanding within the canonical context, as either biblical quotation/paraphrase (Job 39:30) or proverb or sign. This comparison helps to understand that Q 17:37 fits very well to its literary and theological context from these three points of view. It shows therefore a very great semantic flexibility and makes it difficult to establish its original meaning in the document Q. However, the author of the article argues that the Semitic phrase Q 17:37 with a very high probability functioned both in the document $\mathrm{Q}$ and in the canonical context as a quotation/paraphrase of Job 39:30 or as a sign (in the same way as the fig sign in Matt 24:32-33; Luke 21:29-31) rather than as a proverb. The article therefore undermines the classical view that would be consolidated in the modern exegesis on Matt 24:28; Luke 17:37c.
\end{abstract}

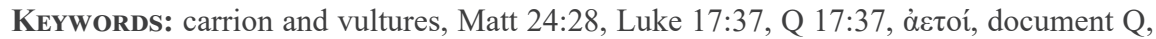
linguistic accommodation, theological accommodation, synoptic tradition

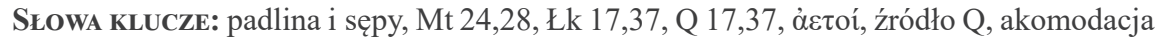
językowa, akomodacja teologiczna, tradycja synoptyczna

Kótki logion Jezusa (Mt 24,28; Łk 17,37c), pochodzący ze źródła Q ${ }^{1}$, przedstawia drobne różnice tekstualne między wersją Mateuszową a Łukaszową. Interpretacja tych różnic może pokazać, jak ewangeliści wykorzystują źródło Q

1 Wydanie krytyczne zrekonstruowanego źródła Q w języku greckim, opublikowane w serii Hermeneia, jest owocem międzynarodowego projektu rozwijanego od 1985 roku: P. Hoffmann J.S. Kloppenborg - J.M. Robinson (red.), The Critical Edition of Q (Hermeneia; Minneapolis, MN: Fortress Press 2008). 
i w jaki sposób dokonują akomodacji słów Jezusa w odpowiednim kontekście, nadając im określony odcień znaczeniowy.

\begin{tabular}{|c|c|c|c|}
\hline & Q 17,37 & Mt 24,28 & Lk $17,37 \mathrm{c}$ \\
\hline Tekst grecki & 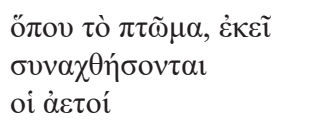 & 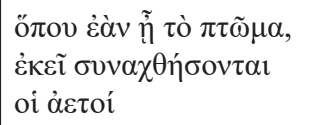 & 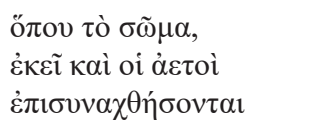 \\
\hline $\begin{array}{l}\text { Tłumaczenie } \\
\text { polskie }\end{array}$ & $\begin{array}{l}\text { Gdzie padlina, tam zgro- } \\
\text { madzą się orły (sępy?) }\end{array}$ & $\begin{array}{l}\text { Gdziekolwiek będzie } \\
\text { padlina, tam zgromadzą } \\
\text { się orły (sępy?) }\end{array}$ & $\begin{array}{l}\text { Gdzie ciało, tam się } \\
\text { i orły (sępy?) zgromadzą }\end{array}$ \\
\hline
\end{tabular}

Tabela 1. Synopsa greckich wersji logionu o padlinie i sępach

\section{Akomodacja językowa i kulturowa logionu Q 17,37 w tradycji synoptycznej}

Porównując wersję Mateuszową i Łukaszową zacytowanego logionu, widać dwie główne różnice. U Mateusza wypowiedź Jezusa ma konstrukcję zdania warunkowego w modus eventualis ${ }^{2}$, stąd protaza ma orzeczenie w coniunctivus praesen-

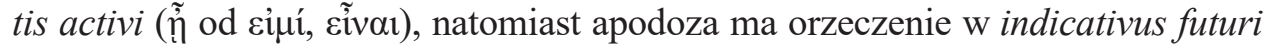

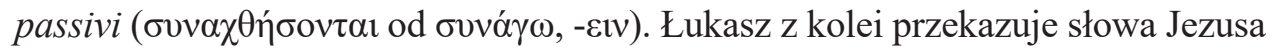
$\mathrm{w}$ formie zdania oznajmującego twierdzącego. Zdanie podrzędne jest równoważnikiem bez orzeczenia, w którym nie zauważa się bezpośrednio odcienia hipotetyczności jak u Mateusza (choć jest ono możliwe). Zdanie główne ma zaś orzecze-

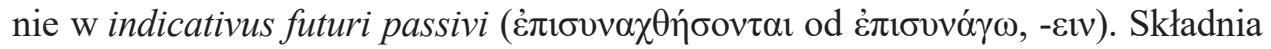
Łukaszowej hipotaksy jest wyraźnie prostsza i ma charakter semityzujący33. To mogłoby sugerować, że Łk 17,37c jest kalką językową Jezusowego logionu, pochodzącego z semickiego oryginału źródła Q. Równoważniki zdań odpowiadają bowiem typowej dla składni hebrajskiej i aramejskiej ${ }^{4}$ formie zdania nominalnego.

2 M. Golias, Gramatyka grecka, wyd. 4 (Warszawa: PWN 1985) 210.

3 Widać to na tle całego dzieła Łukaszowego, gdzie ewangelista wykorzystuje greckie czasy i tryby (nawet tak rzadkie jak optativus) poprawnie i ze zrozumieniem. W szczególności w Dziejach Apostolskich, gdzie nie zależy od źródeł spisanych i pisze z większą płynnością, ukazując swój osobisty styl i wysoki poziom posługiwania się językiem greckim: F. Bovon, Luke. I. A Commentary on the Gospel of Luke 1:1-9:50 (Hermeneia 63A; Minneapolis, MN: Fortress Press 2002) 4-5.

4 Chodzi o język średnioaramejski (200 przed Chr. - 200 po Chr.), nazywany też aramejskim biblijnym bądź żydowskim. Należy jednak pamiętać, że w jego obrębie istnieją oboczności dialektyczne, zauważalne w Księdze Daniela (np. 
Na podstawie analizy syntaktycznej można stwierdzić, że wersja Mateuszowa jest wtórna w odniesieniu do Łukaszowego odpowiednika ${ }^{5}$. Oznacza to, że choć obaj ewangeliści korzystają ze źródła Q niezależnie od siebie ${ }^{6}$, Mateusz dokonuje głębszej filologicznej przeróbki i składniowo dopracowuje Jezusowy logion, dzięki czemu brzmi lepiej i pasuje do języka greckiego ${ }^{7}$. Przekształcając logion, oddala się jednak od jego oryginalnej semickiej formy, której Łukasz pozostał bliższy ${ }^{8}$. To wyjaśniałoby, dlaczego w krytycznym wydaniu źródła Q, zrekonstruowanego w języku greckim, wersja Łukaszowa - nie tylko ze względu na sekwencję logiów ${ }^{9}$ - powinna być podstawowym punktem odniesienia (Łk 17,37c $=\mathrm{Q} 17,37-$ zob. tabela 1$)$. Z tego też powodu przy rekonstrukcji pierwowzoru semickiego (hebrajskiego czy aramejskiego) ${ }^{10}$ powinno się bazować na logionie zapisanym w wersji Łukaszowej ${ }^{11}$.

5 „La formulazione al congiuntivo della protasi in Matteo sembra essere secondaria rispetto all'omissione del verbo, tipica dei proverbi, che riscontriamo in Luca...” (P. Müller, „Velocemente e inevitabilmente - La carogna e gli avvoltoi (Q 17,37)", Compendio delle parabole di Gesù [red. R. Zimmermann] [Brescia: Queriniana 2011] 376).

6 Na to wskazują różnice, jakie zauważamy w porządku perykop należących do tzw. traditio duplex (obecnych jedynie u Mateusza i Łukasza). Inaczej niż w przypadku perykop pochodzących od Marka. Ich porządek u Mt i Łk jest niemal identyczny; R.A. Monasterio - A.R. Carmona, Vangeli sinottici e Atti degli Apostoli (Introduzione allo studio della Bibbia; Brescia: Paideia 1995) 64.

7 Pozwalałoby to spojrzeć nieco inaczej na wykorzystanie źródła Q przez obu ewangelistów, niż przedstawia się w klasycznych badaniach nad źródłem Q - np. Monasterio - Carmona, Vangeli sinottici, 65: „Si ritiene ... che l'ordine originario di Q sia meglio conservato in $L c$., ma che $M t$. rifletta meglio la forma semitica originaria”. Zob. też. Hoffmann - Kloppenborg - Robinson, The Critical Edition of Q, LXXXIX: „It has been generally assumed that Matthew tended to rearrange the sequence of $\mathrm{Q}$ in order to create the longer Matthean discourses, but that Luke tended to retain the sequence of Q" (również przypis 1: „This is the justification for the now widely accepted convention of quoting Q by Lukan chapter and verse numbers...”). Zob. też Müller, „Velocemente e inevitabilmente", 376.

8 Wtórność Mt 25,27 w odniesieniu do Łk 17,37c nie jest rozumiana w sensie czasowym czy w sensie zależności jednego ewangelisty od drugiego, lecz polega na głębszym (niż u Łukasza) przekształceniu struktury syntaktycznej oryginalnego przysłowia z Q 17,37.

9 Tak Hoffmann - Kloppenborg - Robinson, The Critical Edition of Q, LXXXIX (z przypisem 1).

10 Zakłada się, że logia Jezusa w źródle Q zostały spisane w języku aramejskim i później przetłumaczone na język grecki; Monasterio - Carmona, Vangeli sinottici, 64: „Si ritiene che Q fosse una fonte scritta in un primo tempo in aramaico, ma ben presto tradotta in greco". Inaczej John S. Kloppenborg, który w 1987 r. wykluczał istnienie aramejskiego tekstu Q (J.S. Kloppenborg, The Formation of Q. Trajectories in Ancient Wisdom Collections [Studies in Antiquity and Christianity; Philadelphia, PA: Fortress Press 1987] 59: ,...there is no convincing proof of a literary formulation in Aramaic [behind Q-A.Z.]"). W polemice do niego Matthew Black (,The Aramaic Document in Q with Notes on Luke 17.22, Matthew 24.26 (Luke 17.23)", JSNT 40 [1990] 33-41) w 1990 r. ponownie otworzył problem i bronił semickiego oryginału Q.

11 Choć oczywiście niekiedy krytyka tekstu wskazuje, że to wersja Mateusza powinna być punktem wyjścia, i nie tylko jeśli chodzi o sekwencję logiów, jak chcą Paul Hoffmann, John S. Kloppenborg i James M. Robinson (The Critical Edition of $Q$, LXXXIX): ,But in cases where it became clear that the Matthean rather than the Lukan order is that of Q, it is this reconstructed sequence of Q, rather than the Lukan sequence, that is followed". 


\section{Hipotetyczna rekonstrukcja oryginału semickiego Q 17,37}

Rekonstrukcja oryginału semickiego Q 17,37 obejmuje syntaksę zarówno zdania podrzędnego (2.1), jak i nadrzędnego, w którym problemem semantycznym jest

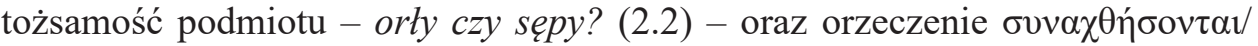
$\dot{\varepsilon} \pi ı v v \alpha \chi \theta \dot{\sigma} \sigma o v \tau \alpha \imath$ (2.3.). Owa rekonstrukcja pozwoli na odtworzenie, niejako à rebour, procesu, który doprowadził do akomodacji językowej i kulturowej Q 17,37.

\subsection{Składnia zdania podrzędnego Q 17,37a}

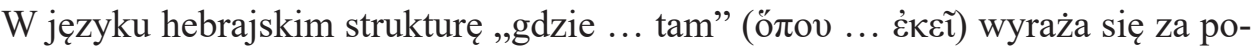
mocą konstruktu krótszego - שֶׁ

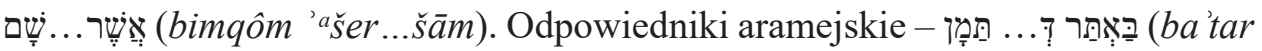

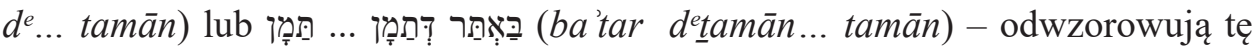
samą konstrukcję zdaniową. Należy zauważyć, że owa konstrukcja, zarówno w języku greckim, jak i w rekonstrukcji oryginału semickiego, zawiera w sobie aspekt nieokreśloności ${ }^{13}$, dlatego sytuacja opisana w przysłowiu może mieć miejsce gdziekolwiek (to będzie miało znaczenie w interpretacji teologicznej). Ponadto na podstawie wersetów Mt 24,28 i Łk 17,37c stwierdza się, że podmiotem zdania podrzędnego w semickim oryginale musiał być rzeczownik w liczbie pojedynczej z rodzajnikiem określonym, oznaczający „ciało” (

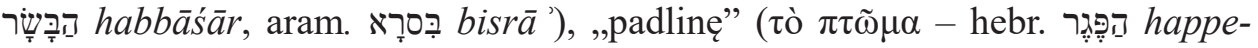

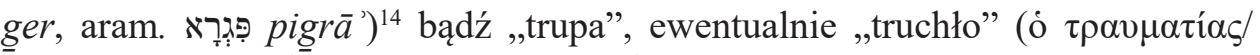

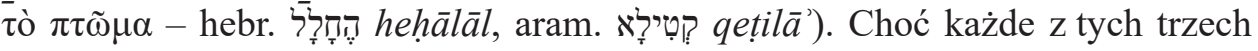
słów mogło być użyte w oryginale semickim, to jednak spośród nich rzeczownik

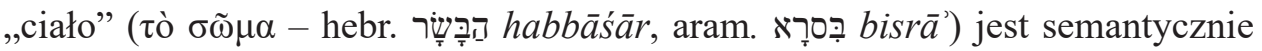
najbardziej pojemny, bo zawiera w sobie wszystkie trzy znaczenia: ciało, padlina i trup (podobnie jak w języku polskim).

12 Analogia z syntaksą Sdz 5,27c.

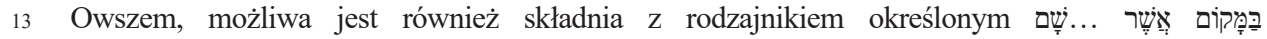

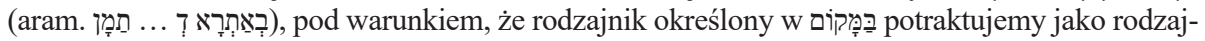
nik ogólny ze znaczeniem „w każdym miejscu, w którym... tam”. P. Joüon, Grammaire de l'hébreu biblique (Roma: PIB 1923) § 137m, s. 425; B.K. Waltke - M. O’Connor, An Introduction to Biblical Hebrew Syntax (Winiona Lake, IN: Eisenbrauns 1990) § 13.5.1f, s. 244.

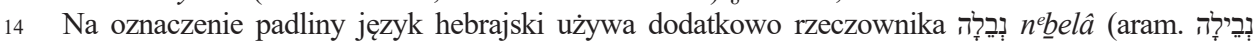
$\left.n^{e} \underline{b} e \hat{l a ̂}\right)$. Dlatego rzeczowniki 
Wybór, które ze słów mogło znajdować się w semickim oryginale, nie jest łatwy. Redaktorzy krytycznego wydania źródła Q - choć opowiedzieli się za uproszczoną konstrukcją syntaktyczną z Łk 17,37c - w tym wypadku poszli za Mt 24,28 i wybrali $\pi \tau \tilde{\omega} \mu \alpha$ („,padlina”) jako lectio difficilior (zob. tabela 1). W ich ocenie Łukasz wykazał się większym wyczuciem językowym niż Mateusz i zamiast słowa „padlina” - zbyt makabrycznego i odrażającego ${ }^{15}$ - używa $\sigma \tilde{\omega} \mu \alpha$ („ciało”) jako terminu bardziej subtelnego i otwierającego się - jak się okaże - na interpretacje alegoryczne, co później - w ślad za Orygenesem ${ }^{16}$ - wykorzystają niektórzy komentatorzy ${ }^{17}$. Subtelność słowa $\sigma \tilde{\omega} \mu \alpha \mathrm{w}$ wersji Łukaszowej stała się dla redaktorów krytycznego wydania Q podstawą do wykluczenia go jako lectio facilior. Ale czy subtelność/niesubtelność danego słowa może być wystarczającym kryterium przy wyborze danej lekcji? Czy nie jest przypadkiem tak, że raczej wieloznaczność rzeczownika $\sigma \tilde{\omega} \mu \alpha \mathrm{w}$ wersji Łukaszowej jest lectio difficilior, podczas gdy zawężenie jego znaczenia do padliny $(\pi \tau \tilde{\omega} \mu \alpha)$ sugerowałoby, że to u Mateusza mamy do czynienia z lectio facilior, bo stanowi pewne uproszczenie? Jeśli więc rzeczownik $\sigma \tilde{\omega} \mu \alpha \mathrm{w}$ wersji Łukaszowej jest lectio difficilior, jego se-

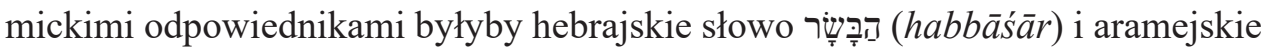
 do jednego znaczenia ${ }^{18}$. W związku z powyższym w niniejszym artykule wybiera

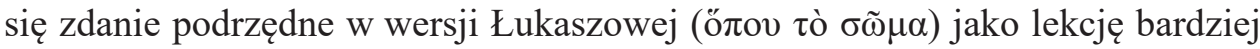
prawdopodobną, wierniej oddającą oryginał semicki źródła Q $\rightarrow$ hebr. (bảa ${ }^{a}$ šer habbāśär $)=$ aram.

\subsection{Składnia zdania nadrzędnego $Q 17,37 b$}

W zdaniu głównym, zarówno w wersji Mateuszowej, jak i Łukaszowej, podmiotem gramatycznym jest rzeczownik w liczbie mnogiej z rodzajnikiem określonym oi ả\&toí („,orły”). Oryginał semicki brzmiał prawdopodobnie po hebrajsku

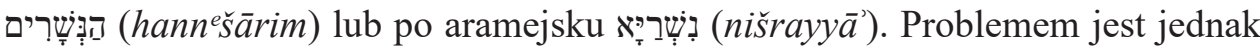
gatunek ptaka, o którym mówi przysłowie. O ile język grecki dokonuje rozróż-

15 Tak też J. Nolland, The Gospel of Matthew. A Commentary on the Greek Text (NIGTC; Grand Rapids, MI: Eerdmans 2005) 980-981; F. Bovon, Luke. II. A Commentary on the Gospel of Luke 9:51-19,27 (Hermeneia 63A; Minneapolis, MN: Fortress Press 2013) 524-525.

16 Zob. przypis 58. Fragment 98 (niepełny) z komentarza Orygenesa do Ewangelii św. Mateusza pojawia się również jako scholion w komentarzu Piotra z Laodycei do Ewangelii św. Mateusza: C.F.G. Heinrici (red.), Des Petrus von Laodicea Erklärung des Matthäusevangeliums (Beiträge zur Geschichte und Erklärung des Neuen Testamentes 5; Leipzig: Dürr 1908) 277, linijki 6-9 + przypisy.

$17 \quad$ Np. przypis w BT V do Łk 17,37.

18 Podobnie J. Topel, „What Kind of a Sign are Vultures? Luke 17,36b”, Bib 84 (2003) 404, przypis 14: „... it is more likely that $\mathrm{Q}$ had $\sigma \tilde{\omega} \mu \alpha$ as the more common term of proverbial speech, and Matthew has specified the original meaning with his $\pi \tau \tilde{\omega} \mu \alpha "$. 


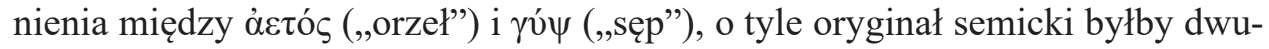
znaczny, bo słowo gatunki należą do tej samej rodziny jastrzębiowatych (Accipitridae), dlatego były mylone przez starożytnych ${ }^{19}$.

\subsubsection{Podmiot - orły czy sępy?}

Spośród 36 gatunków ptaków z rodziny jastrzębiowatych i sokołowatych ${ }^{20}$ występujących w Palestynie, należy wziąć pod uwagę sześć gatunków ptaków, ponieważ ich wygląd i typologia zachowania wydają się odpowiadać treści logionu Q 17,37 i pomagają w jego zrozumieniu.

\subsubsection{Gatunek orła lub sępa pasujący do logionu $Q 17,37$}

Pierwszym gatunkiem jest orzeł przedni (aquila chrysaëtos) - hebr. עִ עִ 'oznîyâ

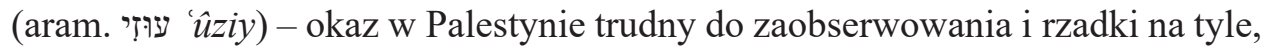
by stał się bohaterem zrozumiałego dla szerszego ogółu przysłowia. Należy go wykluczyć właśnie ze względu na rzadkość występowania (w samej Biblii Hebrajskiej pojawia się zaledwie 2 razy - Kpł 11,13; Pwt 14,12) ${ }^{21}$.

Kolejne dwa gatunki, na które warto zwrócić uwagę, to ścierwnik (neophron

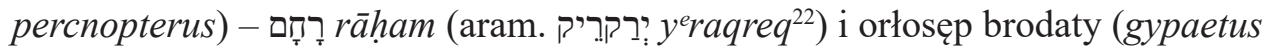

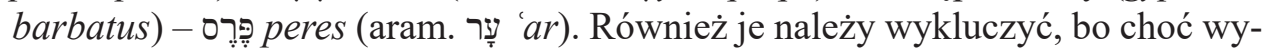
stępują w Palestynie zdecydowanie częściej, nie mają łysej głowy, a taka cecha charakterystyczna przypisana jest ptakowi opisanemu w Biblii Hebrajskiej jako

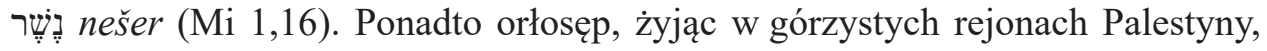
ma zwyczaj rozbijania swych ofiar o skały ${ }^{23}$, na co wskazuje nie tylko łacińska, alternatywna nazwa tego gatunku (vultur ossifragus), ale również jego nazwa

19 W. Speyer, „Geier”, RAC, IX, 439-440.

20 Do początku XX w., na podstawie klasyfikacji Karola Linneusza, orły i sępy były przypisane rodzi-

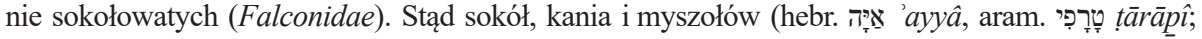

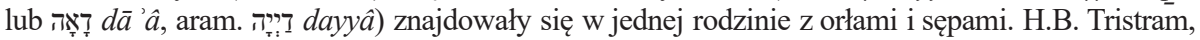
The Fauna and Flora of Palestine (London: The Committee of the Palestine Exploration Fund 1884); przedruk (Cambridge - New York: Cambridge University Press 2013).

21 BT V, thumacząc kle rzadki w Palestynie gatunek ptaka, który występuje na wybrzeżach Syrii i żywi się wyłącznie rybami (nigdy padliną); Tristram, The Fauna and Flora, 107.

22 Semicka nazwa ścierwnika, w szczególności aramejska, prawdopodobnie ma brzmienie onomatopeiczne (http://www.ptaki.info/index_ptaki.php [dostęp 20.10.2020]). Grecki termin ićpa $\xi$ byłby zapożyczeniem z aramejskiego i nie odnosiłby się do sokoła czy jastrzębia (jak się z reguły thumaczy), lecz do ścierwnika.

23 Potwierdza to legenda o śmierci Ajschylosa, która głosi, że orłosęp pomylił łysą głowę poety z kamieniem, na którym chciał rozbić żółwia; Pliny, Natural History X, 3 (red. J. Henderson) (LCL 353; Cambridge, MA - London: Harvard University Press 1983): „Ingenium est ei [=vulturi ossifrago A.Z.], testudines raptas frangere e sublimi iaciendo: quae sors interimit poetam Aeschylum, praedicatam fatis (ut ferunt) eius diei ruinam secura caeli fide caventem". 


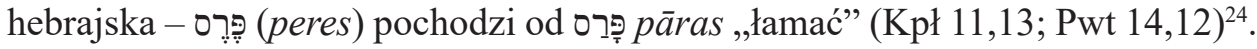
Ten zwyczaj zdobywania pokarmu też nie odpowiada charakterystyce ptaka znanego w Biblii Hebrajskiej jako נְֶֶׁ nešer.

Pozostałe trzy gatunki nie mają osobnych nazw w języku hebrajskim i aramejskim tak, by można było je fachowo odróżnić (co sugeruje, że były mylone): orzeł cesarski (aquila heliaca), sęp płowy (gyps fulvus) i sęp kasztanowaty (aegypius monachus). Jest wielce prawdopodobne, że Biblia Hebrajska słowem

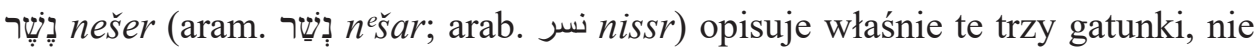
robiąc między nimi jasnego rozróżnienia. Niektórzy badacze są jednak przekonani, że ta nazwa odnosi się głównie do sępa płowego i do bardzo podobnego do niego sępa kasztanowatego, który wyróżnia się ciemniejszym upierzeniem ${ }^{25}$, i nie powinno się jej stosować do orła cesarskiego. Warto jednak zauważyć, że choć orzeł cesarski, jak wszystkie orły, rzeczywiście nie ma łysej głowy, to jednak inne cechy mogły sprawiać, że mylono go z sępem. Jego sylwetka z charakterystycznym upierzeniem przypomina sępa, a ponieważ jest mniej płochliwy, łatwiej można go spotkać i zapamiętać. Ponadto występuje w Palestynie częściej niż orzeł przedni ${ }^{26}$. Częściej można go zaobserwować w pobliżu ludzkich domostw i - co ważne - żywi się również padliną, szczególnie w Palestynie, gdzie o pokarm jest trudno.

\subsubsection{Charakterystyka orła lub sępa pasująca do logionu $Q 17,37$}

A żשָׁרים

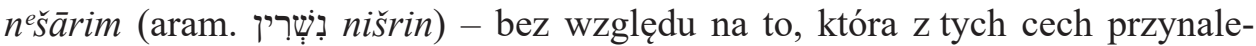
żała do konkretnego gatunku (do sępów czy orłów) - stała się podstawą rozmaitych alegorii, porównań i wyobrażeń. Po pierwsze, sylwetki i zwyczaje tych ptaków były w Palestynie łatwe do zaobserwowania w pobliżu ludzkich siedzib. Dlatego kontakt z nimi stawał się częstym doświadczeniem, budzącym w ludziach tam żyjących podziw i grozę. Po drugie, ptaki te charakteryzowały się

24 Tristram, The Fauna and Flora, 94: „This magnificent bird, the prince of Vultures, may still be seen in most of the mountainous regions of Palestine, but only singly, or a pair together. Its favourite resorts are the gorges opening on the Dead Sea and the Jordan Valley, especially the ravines of the Arnon and the Callirrhoe, .... They are carrion feeders, but marrow-bones, tortoises and snakes are also favourite delicacies. It carries these up to a great height in the air, and then drops them on a rock or stone, repeating the operation till the prey is thoroughly shattered".

25 Tak twierdzi Henry B. Tristram (The Fauna and Flora, 95): „There can be no doubt of the identity of the bird called «Nesher» by the Hebrews with the Arabic «Nissr» the Griffon Vulture, though rendered «Eagle» by our translators. Not only is this evident philologically, but the expression in Micah $(I, 16)$... [Nesher], can only apply to the Griffon”. Zob. też Topel, „What Kind of a Sign are Vultures?", 405-406.

26 „The Imperial Eagle is more numerous throughout the country than the Golden [= aquila chrysaëtos - A.Z.], nor does it, like its congener, disappear in summer... It is bold and comparatively indifferent to the near approach of man and thus its rich dark plumage, white shoulders, and bronzy head may often be admired at leisure" (Tristram, The Fauna and Flora, 99). 
łysą głową, co przywodziło na myśl ogolone głowy jeńców (Mi 1,16; zob. też Iz 7,20) i w określonym kontekście historycznym bez wątpienia mogło być znakiem złowróżbnym. Po trzecie, sępy są najwyżej latającymi ptakami. Mogą wznieść się na wysokość nawet 11 tys. metrów n.p.m. Dlatego budowanie przez nie gniazd w górskich rejonach i szeroka rozpiętość ich skrzydeł (od 2 do niemal $3 \mathrm{~m}$ ) od zawsze kojarzyły się z bezpieczeństwem, opieką i siłą (Wj 19,4; Pwt 32,11; Iz 40,31; Jer 48,40; 49,16.22; Ez 17,3; Hi 39,27-28; Ps 103,5; Ab 4). Po czwarte, sępy, w odróżnieniu od orła cesarskiego, nie lubią latać w pojedynkę (to tłumaczy liczbę mnogą w logionie Jezusa z Q 17,37). Nawzajem obserwują się i zwracają uwagę na znaki pozwalające im spostrzec, czy jeden z nich nie znalazł przypadkiem padliny. Gdy tak się stanie, wykonują szybki manewr polegający na locie schodzącym w dół i do tego stopnia gwałtownym lądowaniu, że po wylądowaniu muszą skakać, by wytracić prędkość.

Orły, z którymi sępy były mylone, są z kolei jednymi z najszybszych ptaków. Orzeł przedni (aquila chrysaëtos) przy locie nurkującym może osiągnąć prędkość nawet $320 \mathrm{~km} / \mathrm{h}$, przypominając pocisk wystrzelony z broni. Zwyczaj żywienia się padliną wymagał dobrego wzroku, szybkości lotu, a charakterystyczny głos odstraszał od żerowiska inne zwierzęta żywiące się padliną (Pwt 28,49; Hi 39,29-30; Prz 23,5; 30,19; Oz 8,1; Hab 1,8). Żywienie się padliną mogło być interpretowane rozmaicie, np. jako oznaka tchórzostwa, żarłoczności i rytualnej nieczystości, której należało unikać (Kpł 11,13; Pwt 14,12). $\mathrm{Z}$ drugiej zaś strony, w środowisku naturalnym taki zwyczaj przyczyniał się do szybkiego usunięcia ciał martwych zwierząt. Pełnił więc funkcję higieniczną, a w przypadku ludzkich zwłok mógł być traktowany nawet jako forma pochów$\mathrm{ku}^{27}$. Jednak Biblia na te dobroczynne skutki działalności orłów i sępów nie zwraca uwagi.

\subsubsection{Akomodacja kulturowa logionu Q 17,37 - orły i sępy u Greków i Rzymian} Starożytne źródła pozabiblijne potwierdzają, że orły i sępy mylono. Dostrzegano ich cechy wspólne, a nie zauważano różnic gatunkowych. Pliniusz Starszy

27 Homer, Iliad IV, 234-238 (red. J. Henderson) (LCL 170; Cambridge, MA - London: Harvard University Press 1924) 181-182: „Niech w was, Grecy, ten zapał szlachetny nie stygnie/Nie za zdrajcami Kronid są prawicę dźwignie/Którzy świętą przysięgę złamali niegodnie/Na brzydką pójdą pastwę sępom za swe zbrodnie“ (tł. F.X. Dmochowski). Zob. też Homer, Odyssey XI, 576-579 (red. J. Henderson) (LCL 104; Cambridge, MA - London: Harvard University Press 1919) 442: „Widziałem i Tityosa, syna Gai świętej/Zalegał dziewięć stajań leżąc rozciągnięty/Dwa sępy, jeden z prawej strony, drugi z lewej/Choć ich spędzał, spod skóry darły z niego trzewy" (tł. L. Siemieński); zob. też ibidem, XXII, 27-30 (LCL 104,346): „Na złe-ć wyjdzie, włóczęgo, żeś śmiał zadrzeć z nami/Ale sztuka od razu! Pójdziesz wnet do ojców/Za zabójstwo pierwszego z itackich mołojców/Żywot twój policzony, sępy cię tu zjedzą" (tt. L. Siemieński). Ponadto zob. też Klaudiusz Elian, O właściwościach zwierząt X, 22 (tł. A.M. Komornicka) (Warszawa: Prószyński i S-ka 2005) 195: „Bakkajowie... tych, którzy oddali życie na wojnie, czczą jak bohaterów...; wobec tego rzucają ich ciała sępom, wierząc, że to święte ptaki”. 
(23-79 po Chr.) w Naturalis historia pod nazwą aquila rozróżnia sześć gatunków orła $^{28}$ : melanaetos, pygargus, morphos (zwany też percnon lub plancus), percnopterus (zwany też oripelargus), gnesion i haliaetus. Nazwy są mylące i nie odpowiadają współczesnej klasyfikacji orłów. Jednak na uwagę zasługuje opis czwartego gatunku, zwanego percnopterus:

Quarti generis est percnopterus: eadem oripelargus, vulturina specie, alis minimis, reliqua magnitudine antecellens, sed imbellis et degener, ut quam verberet corvus. Eadem ieiunae semper aviditatis, et querulae murmurationis. Sola aquilarum exanima fert corpora: ceterae, cum occidere, considunt ${ }^{29}$.

Do czwartego gatunku należy percnopterus: zwany też oripelargus, [orzeł] o wyglądzie sępa, mający bardzo małe skrzydła, poza tym wyróżniający się wielkością, ale tchórzliwy i zwyrodniały do tego stopnia, że kruk jest w stanie go pokonać. Ma nienasyconą żarłoczność i żałosny głos. To jedyny z orłów, który unosi martwe ciała [do góry]: pozostałe [orły], gdy zabiją [swą ofiarę], siadają [przy niej] ${ }^{30}$.

Z tekstu wynika, że percnopterus, którym jest prawdopodobnie orłosęp brodaty, jest zaklasyfikowany jako orzeł, choć z wyglądu i zachowania przypomina sępa. Nie należy tej informacji przypisywać wartości naukowej. Wiemy bowiem, że Naturalis historia bardziej niż encyklopedią jest zbiorem mniej lub bardziej uporządkowanych notatek na rozmaite tematy, zebranych z różnych źródeł. O chaosie u Pliniusza Starszego może świadczyć to, że zachowanie orłosępa przypisane jest aż trzem gatunkom ${ }^{31}$. Wszystko wskazuje więc na to, że Pliniusz czerpiąc swoje informacje $\mathrm{z}$ różnych źródeł, nie był w stanie ocenić ich wiarygodności i nie zauważał, że podając trzy różne nazwy orłów, odnoszące się - w jego mniemaniu - do trzech różnych gatunków (morphos, perconopterus-oripelargus, aquila barbata-ossifraga), tak naprawdę opisuje tego samego ptaka, i - co więcej - ptaka, który nie był orłem. Niektóre informacje Pliniusza dotyczące bezpośrednio sępów potwierdzają jednak, że latają one niezwykle wysoko, budują gniazda w najwyższych partiach gór, a nawet na trzy dni wcześniej

28 „Ex his quas novimus, aquilae maximus honos, maxima et vis. Sex earum genera...” (Pliny, Natural history X, 6 [LCL 353,294]).

29 Pliny, Natural history X, 8 (LCL 353,296). Z tego cytatu korzysta też Müller, „Velocemente e inevitabilmente", 377.

30 Thumaczenie własne.

31 Oprócz opisanego percnoptera, cechy orłosępa wykazuje wspomniany wcześniej morphos i inny gatunek, o którym Pliniusz Starszy pisze: „Quidam adiiciunt genus aquilae, quam barbatam vocant: Tusci vero ossifragam" - Pliny, Natural history X, 11 (LCL 353,298). 
wyczuwają, gdzie pojawi się padlina. Ich obecność była więc uznawana za proroctwo nadchodzącej śmierci ${ }^{32}$.

Fakt, że pojawienie się sępów było wróżbą nadchodzącej śmierci, potwierdza

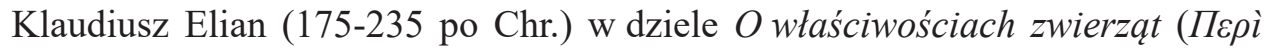

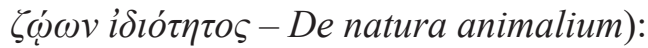

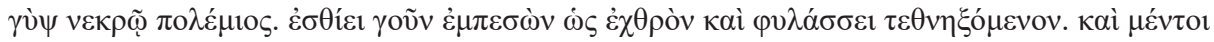

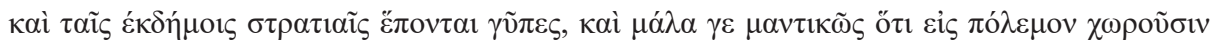

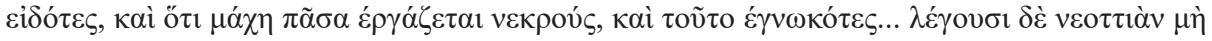

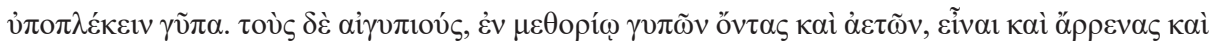

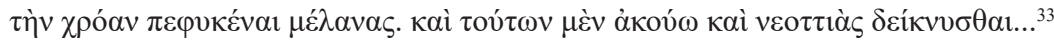

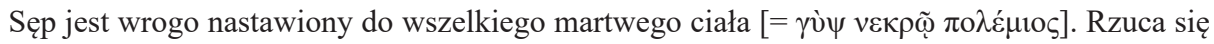
z góry jak na nieprzyjaciela, pożera je albo wyczekuje aż bliskie śmierci stworzenie wyzionie ducha. Sępy podążają za wojskami maszerującymi w obce kraje i wiedzione proroczym

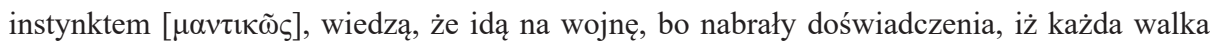
pozostawia trupy... Mówią, że sęp nie wije gniazda. Natomiast sępy kasztanowate [albo orłosępy], będące czymś między sępem i orłem, są również samcami i to o ciemnym upierzeniu. Słyszę, że widziano również jego gniazda... ${ }^{34}$

„Proroczy instynkt” sępów (tu wyrażony za pomocą przysłówka $\mu \alpha v \tau \imath \kappa \tilde{\omega} \varsigma$ ) mógł być wykorzystywany przez ludzi do odczytywania woli bogów i przyszłości ludzkiego losu, w szczególności nadchodzącej śmierci.

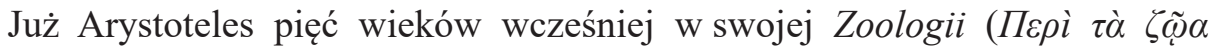

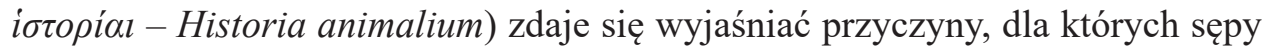
były uważane za ptaki tajemnicze i niewiadomego pochodzenia, co w starożytnym Rzymie augurowie skrzętnie wykorzystywali przy auspicjach i inauguracjach $^{35}$. Opisując zjawiskowość sępów Stagiryta odnotowuje ponadto ich liczebność i zaskakującą gwałtowność pojawiania się:

32 ,[Vulturum - A.Z.] nidos nemo attigit: ideo etiam fuere, qui putarent illos ex adverso orbe advolare, falso: nidificant ... in excelsissimis rupibus... Triduo autem antea volare eos, ubi cadavera futura sunt" - Pliny, Natural History X, 7 (LCL 353).

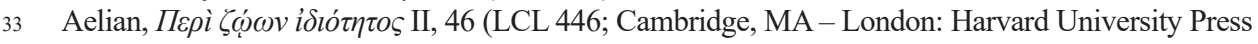
1958) 144. Zob. też I, 45, II, 42, 46; II, 7; IV, 18; XII, 4.

34 Tłumaczenie własne. Por. też Klaudiusz Elian, O właściwościach zwierząt, 6. Elian odnotowuje przekonanie starożytnych, że wszystkie sępy to samice. Dlatego łączono je z wyobrażeniem Wielkiej Bogini, Matki Natury, zapładnianej przez Ozyrysa (w wierzeniach Egipcjan), a w starożytności chrześcijańskiej nawet z osobą Maryi, Matki Bożej, która poczęła Jezusa bez współudziału mężczyzny. Uważano bowiem, że jaja sępicy zapładniał wiatr wschodni.

35 L. Winniczuk, Ludzie, zwyczaje i obyczaje starożytnej Grecji i Rzymu, wyd. 4 (Warszawa: PWN 2008) 577-587 (zwłaszcza 580-581). 


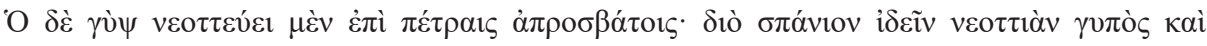

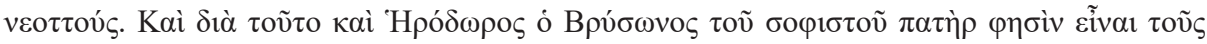

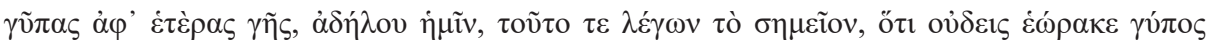

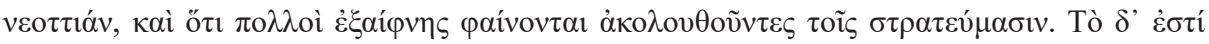

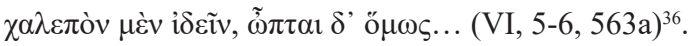

Sęp gnieździ się w niedostępnych skałach; dlatego rzadko można zobaczyć gniazdo sępa i jego młode. I w związku z tym Herodoros, ojciec sofisty Bryzona, mówi, że sępy pochodzą z innej, tajemniczej dla nas ziemi, wskazując taki oto dowód, że nikt dotychczas nie widział gniazda sępa i że [ptaki te] zjawiają się nagle w wielkiej ilości, podążając za wojskami. Rzeczywiście jest rzeczą trudną zobaczyć [gniazdo sępa], jednak już je widziano... (VI, 5-6, 563a) ${ }^{37}$.

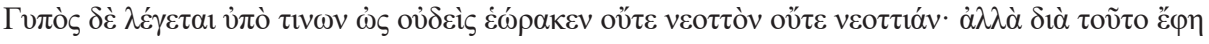

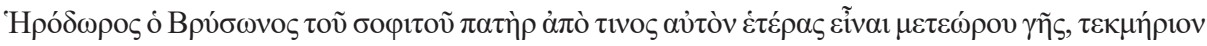

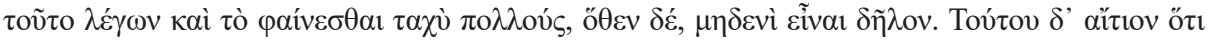

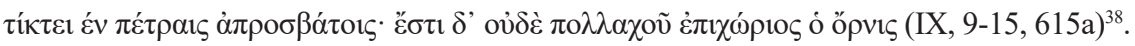

Niektórzy mówią o sępie, że nikt nie widział ani jego młodych, ani jego gniazda. Więc dlatego Herodoros, ojciec sofisty Bryzona, twierdził, że [ten ptak] pochodzi z innego, wysoko położonego kraju, wskazując jako dowód również to, że [sępy] zjawiają się nagle w olbrzymiej ilości, ale skąd? - dla nikogo nie jest jasne. Przyczyną tego jest to, że ten ptak składa jaja w niedostępnych skałach i że żyje w niewielu miejscach (IX, 9-15, 615a) ${ }^{39}$.

Niektóre elementy, obecne w powyższym opisie, pojawią się później u cytowanych już Pliniusza i Klaudiusza Eliana. Arystoteles jednak wydaje się celowo przemilczać wykorzystywanie sępów we wróżbiarstwie. Szkoła perypatetyków, co potwierdza Cyceron w De divinatione, była przeciwna wróżbiarstwu z lotu ptaków czy z wnętrzności zwierzą ${ }^{40}$, a sam Cyceron, choć należał do kolegium augurów, traktował tego typu praktyki z przymrużeniem oka ${ }^{41}$. Według niego

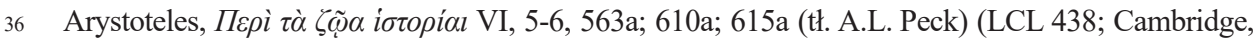
MA - London: Harvard University Press 1970) II, 244-245.

37 Tłumaczenie własne. Zob. też Arystoteles, O duszy. Krótkie rozprawy psychologiczno-biologiczne. Zoologia. O częściach zwierząt (tł. P. Siwek) (Dzieła Wszystkie 3; Warszawa: PWN 1992) 478-479.

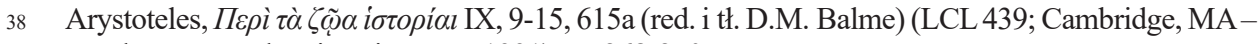
London: Harvard University Press 1991) III, 268-270.

39 Tłumaczenie własne. Zob. też Arystoteles, $O$ duszy, 570.

40 Wspomniani przez Cycerona perypatetycy Dicearch i Kratyppus uznawali jedynie wieszczby ze snów i te wypowiadane w szale proroczym (divinationis genera somniorum et furoris): Cicero, De divinatione I, 5 (red. J. Henderson) (LCL 154; Cambridge, MA - London: Harvard University Press 1923) 228.

41 Cyceron, powołując się na Katona, twierdził, że wróżący z wnętrzności zwierząt hauryspikowie przy przypadkowym spotkaniu uśmiechają się do siebie porozumiewawczo. „Bo co i gdzie sprawdziło się z tego, co oni przepowiedzieli?”; „Vetus autem illud Catonis admodum scitum est, qui mirari se aiebat quod non rideret haruspex haruspicem cum vidisset. Quota enim quaque res evenit praedicta ab istis?" (Cicero, De divinatione II, 52 [LCL 154,428]). 
jedynymi elementami pozwalającymi przewidzieć przyszłość była wiedza i doświadczenie. Jednak fakt, że Arystoteles stara się zrozumieć tajemniczość sępów, może być wskazówką, iż sępy pośród innych ptaków przyciągały ludzką ciekawość i budziły rozmaite skojarzenia (później również te polityczne związane z symbolem orła rzymskiego $)^{42}$.

\subsubsection{Wnioski}

Zarówno ST, jak i źródła pozabiblijne podpowiadają, że ptaki - ả\&toí - w logionie Q 17,37 kojarzyły się ewangelistom i późniejszym słuchaczom nie tyle z konkretnym gatunkiem, ile takimi cechami, jakie w wyobraźni starożytnych ludzi odpowiadały głównie sępom i po części orłom, czyli ptakom nazywanym

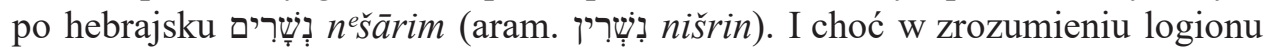
najważniejsze są właśnie cechy tych stworzeń, bardziej niż ich gatunkowa przynależność, to na podstawie naszej wiedzy o ptakach, ich wyglądzie, zachowaniu, zwyczajach i obszarze występowania, możemy doprecyzować, że chodzi prawdopodobnie o sępa płowego, sępa kasztanowatego i orła cesarskiego. Jeśli więc tekst grecki Mt 24,28 i Łk 17,37c opiera się na oryginale semickim, tłumaczenie rzeczownika $\alpha \varepsilon \tau o$ nie powinno bazować na grece klasycznej (,orły”), ale na jego pierwowzorze semickim, który w swej dwuznaczności (,orły” i „sępy”) odnosi się przede wszystkim do sępów. Tłumaczenie zaproponowane w Biblii Tysiąclecia jest więc właściwe i nie powinno być zmieniane.

\subsubsection{Orzeczenie zdania głównego $Q 17,37 b$

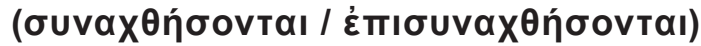

Ostatnim problemem w rekonstrukcji semickiej wersji logionu Q 17,37 jest orzeczenie zdania głównego, które w Ewangeliach kanonicznych ma dwie formy:

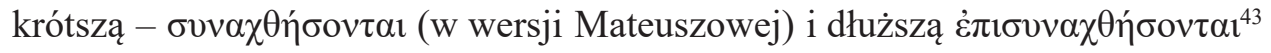
(w wersji Łukaszowej). W zdaniu głównym Mateusz posługuje się czasownikiem $\sigma v v \alpha ́ \gamma \omega$, często spotykanym zarówno w grece klasycznej, jak i w LXX ${ }^{44}$.

42 Tajemniczość orłów/sępów i ich funkcja we wróżbiarstwie mogły być wykorzystane w akomodacji kulturowej logionu Q 17,37, by widzieć w nim zapowiedź nadchodzącej śmierci (zob. niżej § 3.3). Natomiast powiązanie go z rzymskimi orłami niesionymi na drzewcach przed maszerującymi legionami (tak uważa A.R.C. Leaney, Commentary on the Gospel according to St. Luce, wyd. 2 [BNTC; London: Black 1966]; zob. też S. Brown, „The Matthean Apocalypse”, JSNT 4 [1979)] 12) nie ma podstaw w tekście, poza ogólnym skojarzeniem ze zburzeniem Świątyni Jerozolimskiej przez Rzymian w roku 70 po Chr. Po raz pierwszy taką interpretację w 1751 r. zaproponował Johann Jakob Wettstein (Novum Testamentum Graecum [Amsterdam: Dommer 1751] I; przedruk [Graz: Akademische Druck- und Verlagsanstalt 1962] I, 502).

43 Wszystkie trzy typy tekstu Ewangelii św. Łukasza (aleksandryjski, zachodni, bizantyjski) zgodnie przekazują tekst Łk 17,37 bez żadnych wariantów.

44 W rekonstrukcji greckiej wersji źródła Q czasownik ovvóx $\gamma \omega$ pojawia się 6 razy: Q 3,17; 11,23; 12,24; 17,37; 19,21.22. Hoffmann - Kloppenborg - Robinson, The Critical Edition of Q, 1-564. 


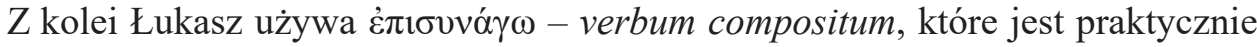
nieobecne w języku greckim klasycznym ${ }^{45}$. Występuje 46 razy w LXX - wyraźnie rzadziej w porównaniu z czasownikiem ovvó $\gamma \omega$, który w LXX pojawia

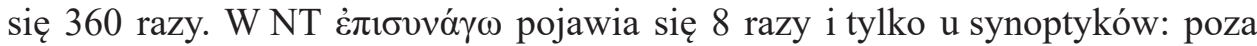
Łk 17,37, w Mt 23,37 (2 razy); 24,31; Mk 1,33; 13,27; Łk 12,1; 13,34.

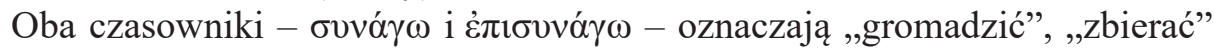
i najprawdopodobniej odtwarzają hebrajski czasownik קִ $q \bar{a} \underline{a} \underline{b} a s^{46}$ bądź aramej-

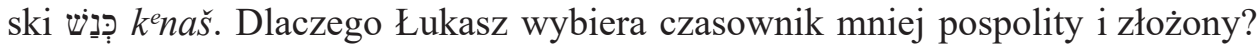
Zakładając, że pozostaje bliższy semickiej formie Jezusowego logionu, można domniemywać, że jest to pewna wskazówka, której nie należy lekceważyć, choć jakiekolwiek jej zrozumienie pozostanie hipotezą i przypuszczeniem.

Łukasz, dostosowując technikę narracyjną do stylu historycznych ksiąg biblijnych, podkreśla ciągłość swej Ewangelii z LXX. Naśladuje język LXX i niewykluczone, że - wybierając nieklasyczny czasownik, który ma jednak zaletę występowania w LXX (46 razy) - kieruje się takim zamysłem. Łukasz nie tyle wybiera semityzmy, ile słowa, wyrażenia i sformułowania typowo biblijne. Verba composita mogą być tego przykładem. Ich użycie jest uwiarygodnione i nobilitowane przez LXX. Ponadto użycie verba composita (choć istniały popularne czasowniki niezłożone w takim samym znaczeniu) już w starożytnych greckich tłumaczeniach ST (alternatywnych do LXX) było pewnym manieryzmem, służącym do jak najwierniejszego odwzorowania oryginału hebrajskiego nawet w liczbie użytych sylab (niekiedy wręcz liter, jak w przypadku tłumaczenia $\mathrm{Akwili}^{47}$ ). Niekiedy za użyciem verba composita kryje się troska thumacza, by jak najwierniej oddać aspekt, funkcję i znaczeniowy odcień hebrajskiej/aramejskiej koniugacji, która wpływała na morfologiczny wygląd hebrajskiego czasownika i jego znaczenie. Mając to na uwadze, można pokusić się o odtworzenie formy morfologicznej semickiego orzeczenia w Q 17,37b.

Po pierwsze, indicativus futuri passivi w języku greckim ( $\sigma v v \alpha \chi \theta \dot{\sigma o v \tau \alpha 1 / ~}$ $\dot{\varepsilon} \pi \iota \sigma v v \alpha \chi \dot{\sigma} \sigma o v \tau \alpha \iota$ ze znaczeniem zwrotnym ${ }^{48}$ - „zgromadzą się”) odpowiada

45 W literaturze greckiej (poza LXX, NT i Flawiuszem) غ̇ंı

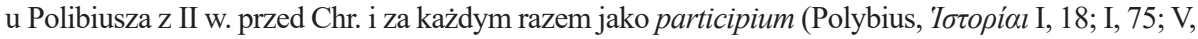
65; V, 95; V, 97; XIV, 1; XIV, 2 [red. J. Henderson] [LCL 128, 138, 159; Cambridge, MA - London: Harvard University Press 2010-2011] I, 52, 220; III, 174, 250, 254; IV, 482, 486).

46 Teoretycznie mógłby być to również czasownik w BH. Ponadto tylko w Qal (nigdy w stronie biernej) i zawsze w znaczeniu ,gromadzić na kupkę", „kolekcjonować”, „odkładać na bok”.

47 „Aquila intende essere fedele alle sillabe e persino alle lettere dell'originale” (N.F. Marcos, La Bibbia dei Settanta [Introduzione allo studio della Bibbia. Supplementi 6; Brescia: Paideia 2000] 123-124).

$48 \mathrm{~W}$ grece NT futurum medii (wraz z aoristum medii) zaczyna zanikać, a jego funkcję przejmuje futurum passivi (,... il futuro e l'aoristo del medio ... cadono in disuso”; F. Blass - A. Debrunner, Grammatica del greco del Nuovo Testamento, wyd. 2 [Introduzione allo studio della Bibbia. Supplementi 2; Brescia: Paideia 1997] 390). Futurum medii będzie nadal używane w NT przy deponentiach i czasownikach, które nie mają formy futurum activi. Można też zauważyć w przypadku niektórych 
hebrajskiej formie imperfectum Nifal lub Hitpael, ponieważ w języku hebrajskim te dwie koniugacje mogą wyrażać stronę zwrotną (reflexivum). Wydaje się

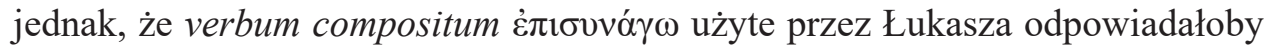
formie Hitpael (aram. Hitpaal) nie tyle ze względów semantycznych, co morfologicznych. Ta forma rozszerza bowiem temat czasownika przez dodanie jednosylabowego przedrostka i podwaja drugą spółgłoskę rdzenną. Mając więcej sylab, jest wyraźnie dłuższa. Jeśli więc Łukasz skrupulatnie chciał odtworzyć semicką formę za pomocą greckiego czasownika, zwracał uwagę również na tego typu niuanse. $Z$ jednej strony starał się zasygnalizować aspekt intensywno-kauzatywny semickiego oryginału, którego greka nie posiada, z drugiej chciał zaś uwypuklić morfologiczne wzdłużenie formy czasownikowej przez dodanie przynajmniej jednej sylaby do greckiego czasownika ${ }^{49}$. Mając więc do wyboru

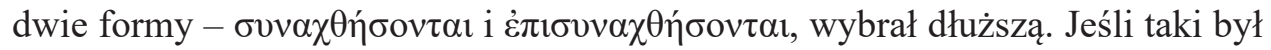
zamysł Łukasza, to jego literalizm przypominałby literalizm Akwili, który na początku II w. po Chr. przetłumaczył Biblię Hebrajską na język grecki ${ }^{50}$. Warto jednak zauważyć, że jeszcze w czasach przedchrześcijańskich, zanim pierwotny Kościół przejął LXX jako „swoją Biblię”, taki literalizm u Żydów był formą sprzeciwu czy nawet odrzucenia LXX, która profanowała Torę przez brak pełnej zgodności $\mathrm{z}$ hebrajskim oryginałem ${ }^{51}$. Literalizm wśród Żydów był więc uzasadniony teologicznie i stawał się wyrazem szacunku dla słowa Bożego. Jeśli więc Łukasz - prozelita, podobnie jak Akwila - wybrał formę czasownika $\dot{\varepsilon} \pi \imath \sigma v v \alpha \chi \theta \eta \dot{\sigma o v} \tau \alpha \iota \mathrm{z}$ takim samym pietyzmem i pedanterią, to niewykluczone, że w ten sposób wyrażał swe przekonanie, iż logion Jezusa stoi na równi ze słowem Bożym zapisanym w Biblii Hebrajskiej.

Po drugie, badania nad translatorskimi technikami wyrażania aspektu kauzatywnego Hifil w tekście LXX doprowadziły do konkluzji, że tłumacze mieli często kłopot z oddaniem tej koniugacji w języku greckim i w tym celu wykorzystywali cały wachlarz możliwości, wśród których verba composita były jedną $\mathrm{z}$ opcji ${ }^{52}$. Jeśli więc Hifil mógł być oddany w grece za pomocą verba composita,

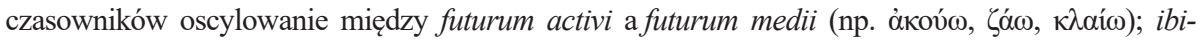
dem, 136.

49 Warto dodać, że jedną z funkcji prefiksu w verba composita jest wzmocnienie znaczenia czasownika („Molte preposioni sono usate come prefissi per intensificare il significato del verbo”; E.G. Jay, Grammatica greca del Nuovo Testamento [Casale Monferrato: Piemme 1993] 313).

50 Pewien rodzaj literalizmu zauważalny jest też w Wulgacie.

51 Marcos, La Bibbia dei Settanta, 59, 117-118.

52 H.St.J. Thackeray, A Grammar of the Old Testament in Greek according to the Septuagint (Cambridge: Cambridge University Press 1909) 289, gdzie w odniesieniu do czasownika $\varphi$ oßźo $\mu \alpha \iota$ dodaje

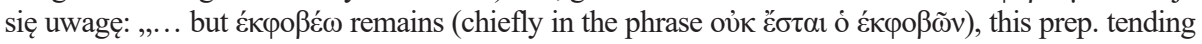

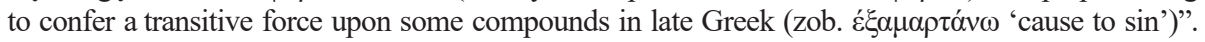
Z kolei Robert Helbing (Die Kasussyntax der Verba bei den Septuaginta. Ein Beitrag zur Hebraismenfrage und zur Syntax der Kolví [Göttingen: Vandenhoeck \& Ruprecht 1928] 80, przypis 1) zauważa, że ,composita with $\kappa \alpha \tau \alpha$ - tend towards a causative meaning”. Odnosząc się do tych sugestii, Emanuel 
to niewykluczone, że również koniugacja intensywno-kauzatywna Hitpael (aram. Hitpaal) mogła być oddawana w taki sam sposób ${ }^{53}$. A zatem również czasownik

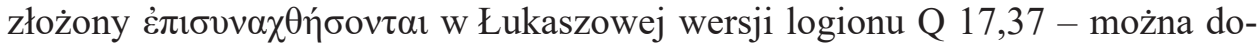
mniemywać - odpowiadałby tej technice translatorskiej.

Po trzecie, w wersji Mateuszowej czasownik ovvóy (Mt 24,28), nie tyle w swej morfologii (jak u Łukasza), ile w składniowej pozycji w obrębie zdania warunkowego, mógłby sugerować (zob. wyżej § 1), że jego semickim pierwowzorem był czasownik w formie intensywno-kauzatywnej Hitpael/Hitpaal. Warto bowiem zauważyć, że skoro forma Hitpael/Hitpaal w języku hebrajskim i aramejskim podkreśla intensywność i wielokrotność czynności, Mateusz mógł celowo wykorzystać konstrukcję zdania warunkowego w modus eventualis, ponieważ w języku greckim taka konstrukcja zawiera w sobie odcień iteratywności ${ }^{54}$. W wersji Mateuszowej mielibyśmy do czynienia z thumaczeniem opartym na tak zwanej ekwiwalencji dynamicznej, polegającej nie tyle na tworzeniu kalki językowej (co - jak się wydaje - robi Łukasz), ile na dokładnym odwzorowaniu myśli autora i jej wewnętrznej dynamiki przy poszanowaniu reguł języka greckiego. Dzięki ekwiwalencji dynamicznej niuanse znaczeniowe, które umykają przy dosłownym thumaczeniu, zostają wiernie zachowane. W ten sposób obie wersje - Łukaszowa w swej dosłowności i Mateuszowa w ekwiwalencji dynamicznej - pozwalają lepiej uchwycić sens przysłowia w jego pierwotnym znaczeniu, i obie - każda na swój sposób - wskazywałyby, że w oryginale semickim orzeczenie zdania głównego było wyrażone za pomocą czasownika w koniugacji intensywno-kauzatywną Hitpael/Hitpaal.

Konkludując, można powiedzieć, że jeśli chodzi o czasowniki użyte w logionie Q 17,37, zdanie podrzędne było z wielkim prawdopodobieństwem (bazując na Łk 17,37c) zdaniem nominalnym, które jako równoważnik zdania, nie miało czasownika w formie osobowej. $\mathrm{Z}$ kolei zdanie główne miało orzeczenie w for-

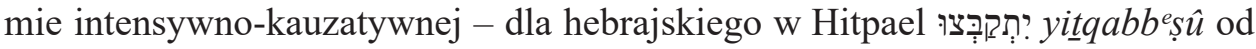

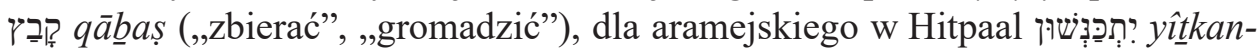
$n^{e}$ šûn od שִ $k^{e}$ naš (,zbierać”, ,gromadzić”). Forma intensywno-kauzatywna Hitpael/Hitpaal jest bardziej prawdopodobna niż forma Nifal (aram. Hitpeel),

Tov („,The Representation of the Causative Aspects of the Hiph' $i$ in in the LXX....... A Study in Translation Technique”, Bib 63 [1982] 417-424 [w szczególności s. 417, przypis 2]) zachowuje ostrożność, ale nie wyklucza, że niektóre verba composita mogą mieć znaczenie kauzatywne: „,...although these statements may be true..., the relevance of this statement to the LXX cannot be investigated easily".

53 Być może do tego nawiązuje lapidarnie Peter Müller (,Velocemente e inevitabilmente”, 376): „,...il

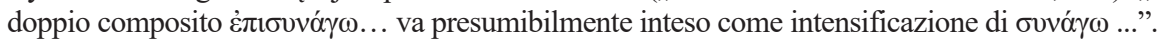

54 Modus eventualis w niektórych przypadkach podkreśla iteratywność czynności, szczególnie gdy w apodozie pojawia się ind. praes. Blass - Debrunner, Grammatica del greco del Nuovo Testamento $\S 373$ (zob. też przypis 2), 452. 
proponowana przez Franza Delitzscha ${ }^{55}$, ponieważ wyraża iteratywność czynności (co odpowiadałoby warunkowości w modus eventualis, obecnej w Mt 24,28), opiera się na rozszerzonej formie rdzenia (co odpowiadałoby użyciu verbum compositum w Łk 17,37c) i lepiej wpisuje się w pole semantyczne czasownika קָב , który w formie zintensyfikowanej odnosi się w większości przypadków do dzikich zwierząt, drapieżników, stad (np. Iz 34,16), ludzi w sytuacjach nieoczekiwanych i przypadkowych (np. Joz 9,2; Sdz 9,47; 1Sm 7,7; 8,4; 22,2; 2Sm 2,25; Iz 44,11; Jr 49,14) oraz nieokiełznanych naturalnych zjawisk (J1 2,6; Na 2,11) ${ }^{56}$, inaczej niż formy Qal i Nifal, które oznaczają przede wszystkim (choć nie zawsze) czynność zaplanowaną z góry i odnoszącą się do ludzkich zgromadzeń, wcześniej przygotowanych w ustalonym miejscu i czasie (np. 1Krl 18,20; Est 2,3; Ezd 8,15; Ne 5,16; 2Krn 32,6).

\subsection{Hipotetyczna rekonstrukcja semickiej wersji logionu $Q 17,37$}

Na podstawie powyższych rozważań (§§ 1-2.2) proponuje się hipotetyczną rekonstrukcję oryginału semickiego logionu Jezusa z Q 17,37 zarówno w języku hebrajskim, jak i aramejskim.

\begin{tabular}{|c|c|c|}
\hline $\begin{array}{l}\text { Możliwe } \\
\text { warianty }\end{array}$ & Wersja hebrajska & Wersja aramejska \\
\hline 1. & 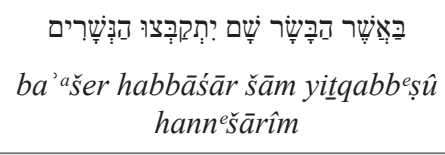 & 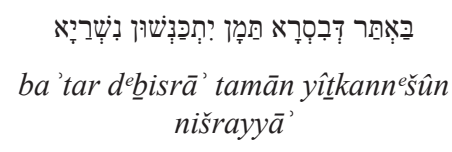 \\
\hline 2. & 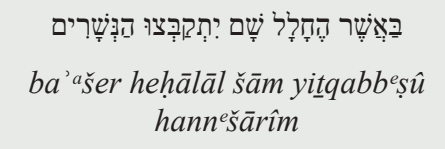 & 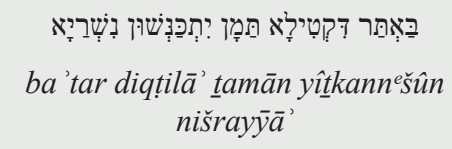 \\
\hline 3. & 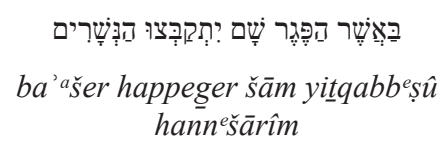 & 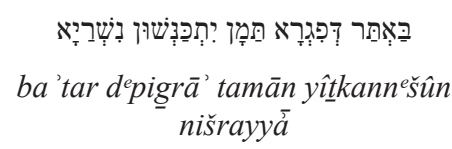 \\
\hline
\end{tabular}

Tabela 2. Hipotetyczna rekonstrukcja oryginału semickiego Q 17,37

55 W 1877 r. Franz Delitzsch opublikował NT w języku hebrajskim biblijnym (czyli jeszcze przed jego reaktywacją jako języka mówionego): חדשה ברית, Hebrew New Testament (זכרת-משפיך: Leipzig 1877). Kolejne 11 wydań tego dzieła były sukcesywnie poprawiane i otrzymały swą ostateczną formę głównie dzięki Gustafowi Dalmanowi w 1892 (G. Dalman, „The Hebrew New Testament of Franz Delitzsch", The Old and New Testament Student 15/3-3 [1892] 147).

56 L. Koehler - W. Baumgartner, The Hebrew and Aramaic Lexicon of the Old Testament (Leiden - Boston, MA - Köln: Brill 2001) II, 1062-1063. 


\subsubsection{Q 17,37 - biblijnym cytatem z Hi 39,30?}

Rekonstrukcja - w zależności od podmiotu zdania podrzędnego - może uwzględnić trzy warianty. Wariant pierwszy, na podstawie dyskusji dotyczącej krytyki tekstu (§ 2.1), wydawał się bardziej prawdopodobny. Jednak przyglądając się zestawionym rekonstrukcjom, a w szczególności wariantowi drugiemu, warto odnotować, że logion Jezusa może być nie tylko odrębnym przysłowiem (jak z reguły się uważa), ale również cytatem-parafrazą z Hi 39,30: „gdzie zabici/

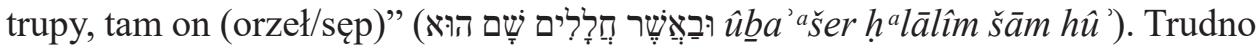
powiedzieć, czy Delitzsch - tłumacząc Mt 24,28 i Łk 17,37c na język hebrajski nie sugerował się wersetem z Księgi Hioba. Tłumacząc Mt 24,28, użył bowiem rzeczownika חָ̣ ḩālāl (,trup”), który w liczbie mnogiej pojawia się w Hi 39,30.

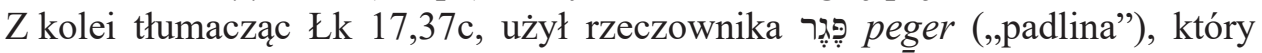
w BH pojawia się 21 razy i jest synonimem częściej używanego rzeczownika חִָ hִălāl (85 razy w BH). Owszem Delitzsch, podobnie jak Gustaf Dalman, był uznanym hebraistą i przy wyborze tego czy innego terminu mógł kierować się doświadczeniem i wyczuciem językowym. Nic nie wiemy o zastosowanych kryteriach, niewykluczone jednak, że tłumacząc logion Jezusa na język hebrajski, rzeczywiście opierał się na Hi 39,3057.

\begin{tabular}{|c|c|}
\hline & Wersja hebrajska wg Delitzscha \\
\hline Mt 24,28 & 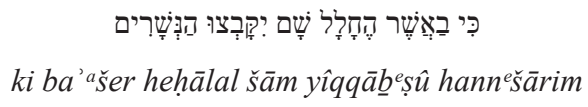 \\
\hline Łk $17,37 \mathrm{c}$ & 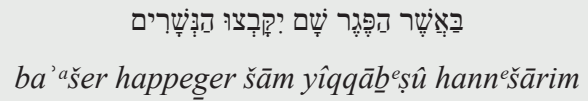 \\
\hline
\end{tabular}

Tabela 3. Hebrajska wersja Mt 24,28 i Łk 17,37c według Franza Delitzscha (1877)

\subsubsection{Końcowy wniosek}

Zaproponowana rekonstrukcja (zob. tabela 2) prowadzi do trzech wniosków. Po pierwsze, logion Jezusa z Q 17,37 w wersji Łukaszowej wydaje się bardziej semityzujący i wierniej oddaje składnię zdania semickiego (hebrajskiego lub

57 Ogólne podobieństwo logionu Q 17,37 do Hi 39,30 odnotowuje A.A.T. Ehrhardt, „Greek Proverbs in the Gospel", HTR 46 (1953) 68-72; zob. też F. Mickiewicz, Ewangelia wedtug świętego Łukasza. Rozdziały 12-24 (NKB.NT 3/2; Częstochowa: Edycja Świętego Pawła 2012) 249. 
aramejskiego). Wersja Mateuszowa z kolei jest przepracowana starannej i dostosowana do niuansów składni języka greckiego. Jeśli zaletą wersji Łukaszowej jest dosłowność, cechą charakterystyczną wersji Mateuszowej jest ekwiwalencja dynamiczna. Obie wersje - każda na swój sposób - uzupełniają się wzajemnie i pomagają w lepszym zrozumieniu Jezusowego logionu.

Po drugie, bazując na zaproponowanych rekonstrukcjach (w szczególności na drugim wariancie $\mathrm{z}$ tabeli 2), można wziąć pod uwagę hipotezę, że logion Q 17,37 użyty przez Jezusa jest cytatem-parafrazą z Hi 39,30 (zob. niżej $\S 3.1$ ). Jeśli tak rzeczywiście było, interpretacja teologiczna logionu najpierw powinna uwzględnić pierwotny kontekst z Biblii Hebrajskiej, czyli fragment Hi 39,26-40,5, a następnie połączyć go z mową eschatologiczną Jezusa w wersji Mateuszowej (Mt 23-25) i Łukaszowej (Łk 17,20-37; 21,5-38). Innymi słowy, Q 17,37 - logion umiejscowiony w kontekście kanonicznym ewangelii Mateusza i Łukasza - byłby punktem konwergencji zamysłu czterech autorów: zamysłu autora Hi 39,30, zamysłu Jezusa i zamysłu dwóch ewangelistów. Mielibyśmy więc ciekawy proces akomodacyjny jednego zdania, w którym zamysł pierwszego autora znajdowałby odbicie w zamyśle drugiego i zyskiwałby nowe niuanse znaczeniowe w zamyśle dwóch ostatnich. Rzutowałoby to na zrozumienie nie tylko logionu Q 17,37, ale i najbliższego kontekstu, w którym się znajduje.

Po trzecie, zaproponowana rekonstrukcja nie wyklucza bynajmniej, że logion Q 17,37 mógł funkcjonować również jako niezależne przysłowie z mądrościowym przesłaniem (zob. niżej § 3.2) lub jako znak eschatycznych wydarzeń (zob. niżej § 3.3). Takie zrozumienie mogłoby rzucić więcej światła na enigmatyczność wypowiedzi Jezusa w kontekście mowy eschatologicznej (Mt 23-25; Łk 17,20-37; 21,5-38).

Te trzy główne wnioski wraz z wskazanymi niuansami syntaktycznymi i semantycznymi będą uwzględnione w interpretacji teologicznej Q 17,37 (zob. niżej § 3).

\section{Akomodacja teologiczna logionu Q 17,37 w mowie eschatologicznej (Mt 23-25; Łk 17,20-37)}

W zależności od tego, jak logion Q 17,37 będzie rozpatrywany - jako cytat-parafraza (§ 3.1), jako niezależne przysłowie (§ 3.2) czy jako znak (§ 3.3) - zmieni się jego znaczenie i funkcja w kontekście mowy eschatologicznej. Dlatego w interpretacji należy rozważyć oddzielenie trzy wymienione możliwości.

W artykule pominiemy jednak interpretację alegoryczną Ojców i doktorów Kościoła, która prowadzi do krępującego (i niemającego podstaw w tekście) 
utożsamienia Jezusa $\mathrm{z}$ ciałem/padliną, a wybranych z sępami (tak św. Ireneusz z Lyonu, Orygenes, św. Ambroży, św. Cyryl Aleksandryjski, św. Hieronim, św. Beda Czcigodny, Eutymiusz Zygaben i Pseudo-Hipolit) ${ }^{58}$ lub (co bardziej

58 Święty Ireneusz (zm. 202): „Hoc ideo quoniam ubicumque est cadaver, illuc congregabuntur et aquilae, participantes gloriae Domini: qui et formavit et ad hoc praeparavit nos, ut dum sumus cum eo participemus gloriae eius" (Irenaeus Lugdunensis, Adversus haereses seu Detectio et eversio falso cognominatae Gnoseos 4, 14,1 [red. E. Dekkers] [Clavis Patrum Latinorum; Turnhout: Brepols 1995] 1154n) (ten fragment w języku greckim nie zachował się); Orygenes (zm. 254): „ő

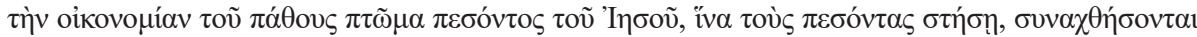

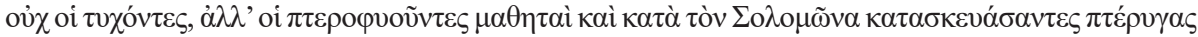

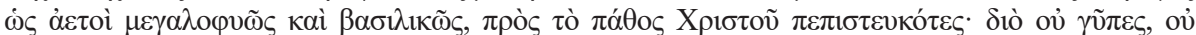

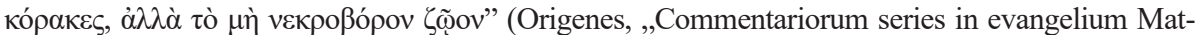
thaei”, fragm. 98, Origenes Werke [red. E. Klostermann] [GSC 38/2; Leipzig: Teubner 1933] XI; tt. pol. K. Augustyniak: Orygenes, Komentarz do Ewangelii św. Mateusza [Kraków: WAM 2002] 81); św. Ambroży (zm. 397): „Nonne tibi videntur aquilae circa corpus Maria Cleopae et Maria Magdalene et Maria Mater Domini apostolorumque conventus circa Domini sepulturam?" (Ambrosius, Expositio evangelii secundum Lucam, 8, 634 [red. M. Adriaen] [CCSL 14; Turnhout: Brepols 1957]; tł. pol. W. Szołdrski: Ambroży, Wykład Ewangelii wedlug św. Łukasza 8, 55-56 [red. A Bogucki] [PSP 16; Warszawa: ATK 1977] 77); św. Hieronim (zm. 420): „Aquilae et vultures etiam trans maria dicuntur sentire cadavera et ad escam huiuscemodi congregari. Si ergo inrationabiles volucres naturali sensu tantis terrarum spatiis et maris fluctibus separatae parvum cadaver sentiunt ubi iaceat, quanto magis nos et omnis multitudo credentium debet festinare ad eum cuius fulgur exit ab oriente et paret usque ad occidentem. Possumus autem corpus, id est $\pi \tau \tilde{\omega} \mu \alpha$, quod significantius latine dicitur cadaver ab eo quod per mortem cadat, passionem Christi intellegere ad quam provocamur ut ubicumque in scripturis legitur congregemur, et per illam venire possumus ad Verbum Dei..." (Hieronymus, Commentarii in evangelium Matthaei 4, 531 [red. E. Dekkers] [CPL; Turnhout: Brepols 1995]

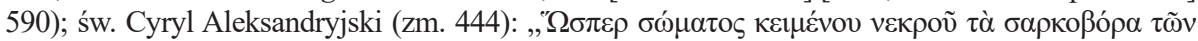

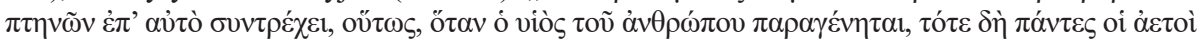

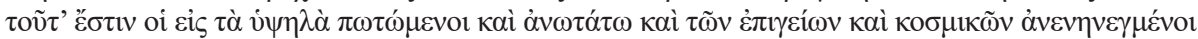

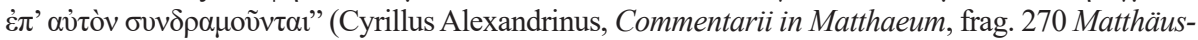
-Kommentare aus der griechischen Kirche [red. J. Reuss] [TU 61; Berlin: Akademie 1957] 153-269); św. Beda Czcigodny (zm. 735): „,.. dixit eis: ubicumque fuerit corpus illuc congregabuntur aquilae. Duo Salvator interrogatus, ubi scilicet boni assumendi et ubi sint mali relinquendi unum dixit aliud subintellegendum reliquit. Sanctos enim secum futuros asseverando reprobos nimirum a sua visione secernendos et ideo non alibi quam cum diabolo damnandos insinuat. Ubicumque ergo fuerit Dominus corpore illo congregabuntur electi, qui eius passionem humilitatemque imitando tamquam de eius carne saturantur quorum per resurrectionem renovabitur ut aquilae iuventus. Concinit etiam studiis eorum, qui gloriam supernae maiestatis tota mente contemplari sitiunt quod aquila ceteras aves volatu transgrediens in ipsum solis radium oculos gaudet infigere. Congruit et illud quod aetiten lapidem venenis resistentem suis nidis solet afferre ne forte serpens accedere vel pullos aut ova sua tangere praesumat quia videlicet omnis sapiens ut actus cogitatusque suos ab antiqui serpentis valeat irruptione defendere illum necesse est lapidem qui praecisus de monte sine manibus diaboli regnum stravit, hoc est fidem dilectionemque Christi suo semper in pectore servet" (Beda Venerabilis, In Lucae evangelium expositio 5, 17, 1027 [red. E. Dekkers] [Clavis Patrum Latinorum; Turnhout: Brepols 1995] 1356); Eutymiusz Zygaben (zm. 1120): „Toṽ

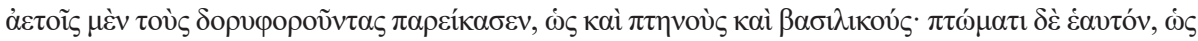

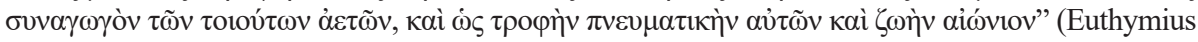
Zigabenus, Commentarius in quatuor evangelia 1, 617 ; 3, 1052 [PG 129,9-1502]); Pseudo-Hipolit: ,„̋̈

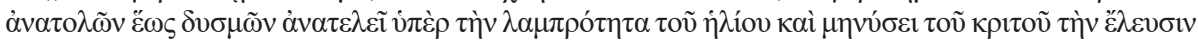

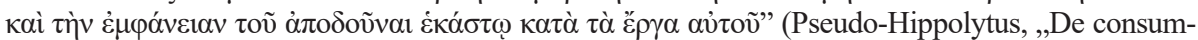


możliwe) utożsamienia paruzji z sępami, a grzeszników z padliną (tak św. Hipolit Rzymski i Apolinary z Laodycei $)^{59}$.

\subsection{Q 17,37 jako cytat-parafraza (illud dictum) z Hi 39,30}

Jeśli logion Q 17,37 jest cytatem-parafrazą z Hi 39,30, to pełni konkretną funkcję w mowie eschatologicznej zarówno u Mateusza, jak i u Łukasza.

\subsubsection{Hi 39,30 w mowie eschatologicznej w Ewangelii Mateusza}

U Mateusza Jezus, mówiąc o przyjściu Syna Człowieczego, które porównuje do błyskawicy obejmującej swym blaskiem cały nieboskłon od wschodu do zachodu (Mt 24,27), dodaje ni stąd, ni zowąd parafrazę wersetu o sępach i padlinie z Hi 39,30. Na pierwszy rzut oka owa parafraza nie pasuje do obrazu przyjścia Syna Człowieczego. Ma się wrażenie, że jest sztucznie doczepiona, by dać jakiś niezrozumiały rodzaj konkluzji czy w osobliwy sposób uwypuklić zarysowany obraz. Jednak jeśli weźmiemy pod uwagę, że Hi 39,30 jest wyjęty z szerszego fragmentu mówiącego o wszechmocy Boga i niewiedzy człowieka (Hi 39,26-40,5), intencja Jezusa staje się jasna. Stosując zabieg typowo midraszowy, Jezus przywołuje na myśl odpowiedni tekst z Pisma Świętego, by przypomnieć uczniom, że nie jest im dane wiedzieć czy wyliczyć, kiedy nastąpi moment paruzji, ponieważ jest on znany jedynie Bogu. Właściwą postawą wobec

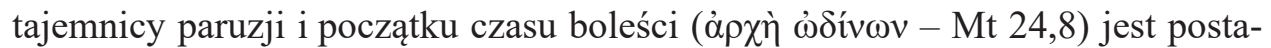
wa Hioba wyrażona w słowach: ,jestem mały, cóż Ci odpowiem! Rękę położę na ustach. Raz przemówiłem i nie odpowiem, i drugi raz, a niczego nie dodam"

matione mundi", 13, 12, Hippolyt's kleinere exegetische und homiletische Schriften [red. H. Achelis] [GCS 1/2; Leipzig: Teubner 1897] 289-309); zob. też J. de Marchi, „Ubicumque fuerit corpus, ibi congregabuntur et aquilae”, VD 18 (1938) 329-333; G. Rossé, Il Vangelo di Luca. Commento esegetico e teologico, wyd. 3 (Roma: Città Nuova 2001) 681; T.J. Lang, „"Where the Body Is, There also the Eagles Will Be Gathered»: Luke 17:37 and the Arrest of Jesus", BibInt 21/3 (2013) 320-340.

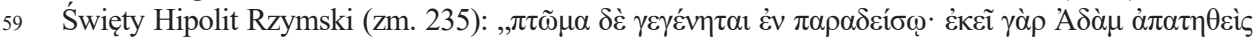

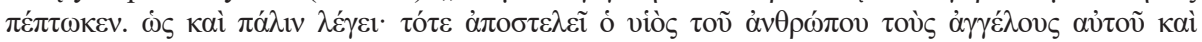

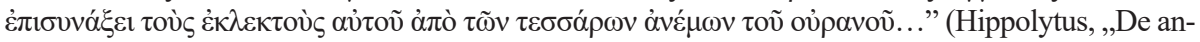
tichristo" 64, 14, Hippolyt's kleinere exegetische und homiletische Schriften [red. H. Achelis] [GCS

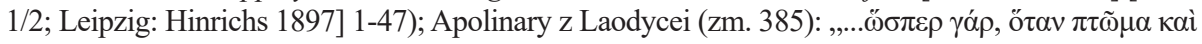

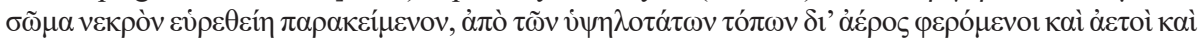

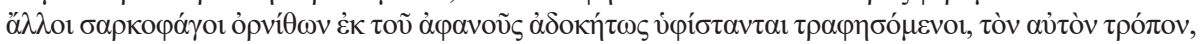

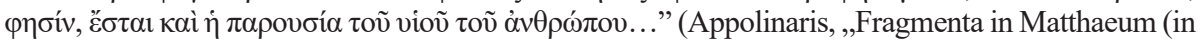
catenis)" frag. 125-126, Matthäus-Kommentare aus der griechischen Kirche [red. J. Reuss] [TU 61; Berlin: Akademie 1957] 43); zob. też A. Stöger, Vangelo secondo Luca, wyd. 4 (Commenti spirituali del Nuovo Testamento; Roma: Città Nuova 1994) II, 115: „Come gli uccelli di rapina sono attirati dai cadaveri, così sarà attirato sul mondo il giudizio di condanna dagli uomini peccatori”. 
(Hi 40,4-5). Gdy do tego dodamy zachętę do czuwania: „Czuwajcie więc, bo nie wiecie, w którym dniu Pan wasz przyjdzie" (Mt 24,42nn), mamy pełny obraz ewangelicznego oczekiwania. Powinno się ono charakteryzować z jednej strony pokorą wobec wszechwiedzy Boga (= rezygnacja z fanatyzmu apokaliptycznego, chcącego wyliczyć moment paruzji), z drugiej zaś - aktywnym czuwaniem (= właściwe odczytywanie Bożych znaków: „...od drzewa figowego uczcie się przez podobieństwo..." - Mt 24,32a).

\subsubsection{Hi 39,30 w mowie eschatologicznej w Ewangelii Łukasza}

U Łukasza mowa eschatologiczna rozbita jest na dwie części: krótszą (Łk 17,20-37) i dłuższą (Łk 21,5-38). Parafraza z Hi 39,30 (= Łk 17,37c) jest ostatnim wersetem krótszej mowy eschatologicznej (Łk 17,20-37) i stanowi jej

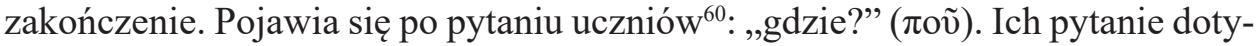
czy losu dwojga ludzi, z których jedno będzie wzięte od swej codzienności, drugie zostawione. Uczniowie zaciekawieni plastycznością i tajemniczością obrazu, pytają: gdzie to się stanie lub gdzie owi ludzie zostaną wzięci bądź zostawieni? W odpowiedzi Jezus mówi: „gdzie jest ciało $(\sigma \tilde{\omega} \mu \alpha)$, tam się i sępy zgromadzą”. Można pomyśleć, że Jezus wskazuje na miejsce wypełnienia się proroctwa. Jeśli jednak ponownie weźmiemy pod uwagę możliwość, że Q 17,37 jest cytatem-parafrazą z Hi 39,30, to odpowiedź Jezusa jest „biblijnym unikiem” i funkcjonuje tak samo jak w wersji Mateuszowej. Nawiązując do fragmentu z Hi 39,26-40,5, zachęca uczniów do pokładania ufności w Bogu i - choć „świerzbi” ich ludzka ciekawość - wskazuje, że jedynym przygotowaniem na przyjście Pana jest modlitwa (inaczej niż u Mateusza). Dlatego zaraz po Q 17,37 (=Łk 17,37c) ewangelista przytacza przypowieść o niesprawiedliwym sędzim i o potrzebie wytrwałej modlitwy, która jest wyrazem ufności Ojcu: ,,ale czy Syn Człowieczy znajdzie wiarę na ziemi, gdy przyjdzie?" (Łk 18,8). Podobna sytuacja ma miejsce, gdy uczniowie pytają o czas przywrócenia królestwa Izraela w Dz 1,6-7. Jezus w odpowiedzi upomina ich i wskazuje na wszechmoc Boga: „nie wasza to rzecz znać czasy i chwile, które Ojciec ustalił swoją władzą ( $\dot{\varepsilon} \xi o v \sigma i ́ \alpha) "$.

\subsubsection{Różnice w wykorzystaniu Q 17,37 - zamysł akomodacyjny}

Obaj ewangeliści umieszczają logion Q 17,37 w dwóch różnych miejscach w mowie eschatologicznej. Tam, gdzie Łukasz umieszcza logion o padlinie i sępach (Łk 17,34-37), Mateusz w paralelnym miejscu (Mt 24,40-42) przekazuje słowa o czuwaniu: „czuwajcie więc, bo nie wiecie, w którym dniu Pan wasz przyjdzie" (Mt 24,42). Z kolei tam, gdzie Mateusz mówi o błyskawicy obejmu-

60 Jednak nieco wcześniej pytającymi byli faryzeusze - Łk 17,20.22. 
jącej swym blaskiem cały widnokrąg i dodaje logion Q 17,37 (Mt 24,27-28), Łukasz w paralelnym miejscu (Łk 17,24-25) podaje zapowiedź pasji: „wpierw jednak [Syn Człowieczy] musi wiele wycierpieć i być odrzuconym przez to pokolenie" (Łk 17,24). Ponadto u Mateusza logion Q 17,37 ma charakter konkluzyjnego komentarza do proroctwa z Mt 24,27, a u Łukasza przybiera formę odpowiedzi (wymijającej) na postawione wcześniej pytanie. Oznacza to, że albo logion Q 17,37 nie był ściśle powiązany z jedną wypowiedzią Jezusa, skoro u ewangelistów jest połączony $z$ dwiema różnymi wypowiedziami, albo jeden z ewangelistów zachował pierwotny związek Q 17,37 z konkretną wypowiedzią Jezusa, drugi zaś dokonał modyfikacji i połączył logion z inną wypowiedzią Jezusa. W badaniach nad źródłem Q przyjmuje się, że to Łukasz przekazał wierniej pierwotną sekwencję logiów Jezusa ${ }^{61}$, dlatego nie wyklucza się, że logion Q 17,37 w źródle Q był odpowiedzią na pytanie uczniów, tak jak w Ewangelii Łukasza. Ale pewności nie ma.

Jednak u obu ewangelistów logion Q 17,37 - rozumiany jako cytat-parafraza z Hi 39,30 - ma takie samo znaczenie: jest wezwaniem do uznania własnej niewiedzy i bezsilności wobec wszechmocy Boga, która objawia się w wydarzeniach poprzedzających paruzję. Nie jest to wezwanie do biernego trwania, lecz do udzielenia pozytywnej odpowiedzi Bogu, który nadchodzi. Różnica polega na tym, że odpowiedź, jakiej Jezus oczekuje od uczniów, jest inna u Łukasza, a inna u Mateusza. U Łukasza jest nią pokorna i nieustanna modlitwa (Łk 18,1-8; ale też 18,9-14) oraz misyjna otwartość na działanie Ducha Świętego (Dz 1,7-8). U Mateusza z kolei jest to pokorna kontemplacja otaczającej rzeczywistości, w której Bóg rozsiewa znaki ( $\sigma \eta \mu \varepsilon i ̃)$ nadchodzącego przełomu. Jeśli Łukasz wzywa do intymnej relacji z Ojcem i do przyjęcia daru Ducha Świętego, by być świadkiem Jezusa, Mateusz wzywa wspólnotę do prorockiego spojrzenia na dzieło stworzenia. To wezwanie u Mateusza może być reminiscencją dwóch poetyckich wypowiedzi Boga z Hi 38-41. Hiob, zarzucając Bogu, że niezasłużone cierpienie człowieka jest dowodem na panujący we wszechświecie nieporządek i chaos, żąda wyjaśnień (Hi 13,20-22; 31,35-37). Bóg ze swej strony - podejmując wyzwanie - ukazuje dzieło stworzenia i skomplikowany mechanizm rządzący wszechświatem, w którym odbija się Boża mądrość, niedostępna w swej istocie dla ludzkiego umysłu. Jeśli całe stworzenie pozostaje pod władzą Boga chce powiedzieć autor biblijny - to również cierpienie człowieka musi mieć cel i znaczenie. Podobnej wiary Jezus wymaga od uczniów wobec cierpień, prześladowań i wewnętrznych rozłamów, które poprzedzą paruzję.

Mateusz, pisząc do judeochrześcijan wychowanych na Piśmie Świętym, uwypuklił znaczenie i konsekwencje logionu Q 17,37 w świetle ST, w szczególności Księgi Hioba: skoro nie możecie zrozumieć ani obliczyć czasu boleści poprze-

61 Zob. wyżej przypis 7. 
dzającego paruzję, obserwujcie uważnie to, co dzieje się dokoła was - w historii i przyrodzie - a dostrzeżecie znaki Bożych decyzji. Łukasz z kolei, pisząc do etnochrześcijan, nie wykorzystał tych biblijnych reminiscencji, ale dał bardziej jednoznaczne wskazania: modlitwa i świadectwo życia w Duchu są nieodzownym przygotowaniem do nadchodzącego końca. Obaj ewangeliści, umieszczając logion Q 17,37 w odpowiednim miejscy mowy eschatologicznej, potwierdzają, że paruzja to nie kwestia wiedzy czy kontroli człowieka, lecz wezwanie do otwartości na działanie Boga, gdziekolwiek się ono objawia: w duszy człowieka, w jego życiu, radości i smutku czy otaczającej rzeczywistości. Obraz padliny i sępów, zaczerpnięty z obserwacji przyrody, wywołuje odrazę, podobnie jak inne okropności, które zapowiada mowa eschatologiczna. Trudno w tych zjawiskach dostrzec przychodzącego Boga. Stąd tym usilniejsze wezwanie do ufnego czuwania.

\subsubsection{Końcowy wniosek}

Logion Q 17,37 w mowie eschatologicznej byłby cytatem-parafrazą Hi 39,26-40,5 - nawiązywałby do fragmentu, w którym mówi się o niezdolności zrozumienia Bożego zamysłu, o potrzebie uznania własnej ograniczoności i pokładaniu ufności w Bogu wobec Jego nieogarnionej wszechmocy. U Mateusza logion 17,37 stanowiłby biblijny komentarz do zapowiedzi przyjścia Syna Człowieczego, u Łukasza zaś - wymijającą odpowiedź na pytanie uczniów (podobnie jak w Dz 1,7-8: ,nie wasza to rzecz...”), odsyłającą ich do wszechmocy Boga tematu wielokrotnie poruszanego w ST, jak w Hi 39-41.

Ten sposób wplatania odniesień do ST jest typowy dla Miszny, Talmudu i hebrajskiej masory, gdzie cytaty bądź parafrazy z Pisma Świętego były wprowadzane za pomocą” „czy nie czytaliście, że...”, ,jest napisane, że ...”, lub asyndetycznie, bez żadnego spójnika czy wprowadzenia, po czym następowały pierwsze bądź najbardziej charakterystyczne słowa przytaczanego tekstu. Ten sposób cytowania odpowiadałby naszym siglom, umieszczanym w nawiasie. I dopóki podział Biblii na rozdziały, wprowadzony przez arcybiskupa Canterbury Stephena Langtona (1155-1228), nie zaczął być powszechnie stosowany od XIII wieku ${ }^{62}$ - a podział na wersety jeszcze później, bo od XVI wieku - cytaty i odniesienia biblijne były sygnalizowane w ten właśnie sposób i jeśli ktoś nie znał dobrze Pisma Świętego, mógł ich nie zauważyć lub potraktować na równi z okalającym kontekstem. Niewykluczone, że zdanie „gdzie jest padlina, tam zgromadzą się i sępy" jest właśnie takim odniesieniem, które z biegiem czasu padło ofiarą niewiedzy czytelników, tracąc rangę biblijnego cytatu.

62 R.B. Zuck, Basic Bible Interpretation. A Practical Guide to Discovering Biblical Truth (Colorado Springs, CO: Cook 1991) 43. 


\subsection{Q 17,37 jako niezależne przysłowie (proverbium)}

W klasycznej egzegezie logion Q 17,37 jest uważany za niezależne przysłowie ( czy, łączący padlinę z sępami. Jeśli obecność padliny zapowiada niechybne, szybkie i punktowe pojawianie się sępów, trzy elementy: niechybność, szybkość i punktowa dokładność („tam, gdzie”), tworzą hermeneutyczną oś, wokół której egzegeza buduje swe interpretacje.

Punktem wyjścia jest proste przesłanie: paruzja nadejdzie nieuchronnie, nagle i w każdym możliwym miejscu, podobnie jak pojawienie się sępów wokół padliny lub jak błyskawica, po której zaraz rozbłyska światło rozświetlające widnokrąg (Mt 24,27-28) ${ }^{64}$. Związek przyczynowo-sprawczy jest obecny w obu obrazach, choć - jak się okaże - nie wiadomo, czy ewangeliści, w szczególności Łukasz, łączyli je w takim właśnie kluczu.

Zrozumienie logionu wymaga nie tylko wyobraźni, ale i znajomości prawi-

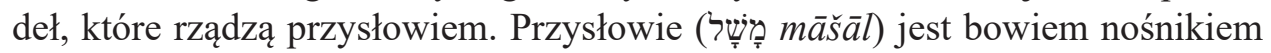
uniwersalnych prawd, zrozumiałych dla człowieka w każdym miejscu i czasie. Rodzi się po uważnej obserwacji rzeczywistości jako owoc doświadczenia wielokrotnie przeżytego, opowiedzianego i sprowadzonego do krótkiego aforyzmu, łatwego do zapamiętania, niekiedy w enigmatycznej formie. Tak jak morał w bajce, przysłowie syntetyzuje refleksję nad ludzkim doświadczeniem. Ma charakter konkluzji i ogólnego wniosku ${ }^{65}$. Wobec zawiłości ludzkich doświadczeń, które wymykają się zrozumieniu, przysłowie pozwala spojrzeć na życie w jego prawdzie, wyrwać je z chaosu i nonsensu, i sprowadzić do wspólnego mianownika, prostego i dostępnego każdemu. Dlatego prawda zawarta w przysłowiu o padlinie i sępach wydaje się oczywista i samonarzucająca się. Jednak w kontekście ewangelicznym to przysłowie już takie oczywiste nie jest. A to może sugerować, że - jako pewien skrót myślowy - mogło oznaczać w kulturze żydowskiej coś innego, niż nam się wydaje. Kod kulturowy zapisany w przysłowiach nie zawsze prowadzi prostą drogą do uniwersalnej prawdy, która jest w nich ukryta. Może być barierą nie do pokonania, jeśli nie zna się literackich kontekstów, w których wykorzystywano przysłowie, lub skojarzeń, jakie wywoływało ${ }^{66}$. W odcyfrowaniu znaczenia przysłowia bazuje się więc na jego treści i wewnętrznej logice,

63 Topel (,What Kind of a Sign are Vultures?”, 403-411) zakłada bez żadnej dyskusji, że Q 17,37 jest przysłowiem. Zob. też H.O. Guenther, „When ‘Eagles’ Draw Together”, Forum 5 (1989) 140-150.

64 Tak większość komentatorów, co potwierdza Antoni Paciorek (Ewangelia wedlug świętego Mateusza. Rozdziały 14-28 [NKB.NT 1/2; Częstochowa: Edycja Świętego Pawła 2008] 464).

65 M. Gilbert, La sapienza del cielo (Milano: Edizioni San Paolo 2005) 21-22; D. Scaiola, „La sapienza in Israele e nel Vicino Oriente antico", Libri sapienziali e altri scritti (red. A. Bonora - M. Priotto) (Torino: Editrice Elledici 2005) 37.

66 Np. przysłowie ,trzeba pocałować wiele żab, zanim znajdzie się swojego księcia”, bez znajomości odpowiedniego kontekstu kulturowego, pozostawałoby niezrozumiałe. 
na zdrowym rozsądku i na dwóch kontekstach (Mateuszowym i Łukaszowym), w których się pojawia. Niestety to za mało, by sformułować jednoznaczną interpretację, wokół której panowałaby powszechna zgoda egzegetów. Spróbujmy jednak pójść tropem wyznaczonym przez związek przyczynowo-sprawczy obecny w logionie.

\subsubsection{Q 17,37 jako przysłowie u Mateusza (Mt 24,28)}

U Mateusza Q 17,37 może być porównaniem ( $\pi \alpha \rho \alpha \beta$ nagle, jak pojawienie się sępów wokół padliny. Uczeń Jezusa wobec dynamizmu paruzji powinien przyjąć postawę mądrościową i obserwować uważnie rozsiane w świecie znaki, by nie był zaskoczony gwałtownością eschatycznych wydarzeń. Powinien dotrzeć do Bożej mądrości odciśniętej w stworzeniu i w mechanizmach, które nim rządzą. Potwierdza to inny motyw użyty przez Jezusa nieco dalej: „od drzewa figowego uczcie się przez podobieństwo ( $\pi \alpha \rho \alpha \beta o \lambda \eta \eta \eta) ”$ (Mt 24,32-33).

Asyndetyczne (= bezspójnikowe) dołączenie Q 17,37 na końcu perykopy Mt 24,23-28 uwypukla dodatkowo charakter mądrościowy i konkludujący tego przysłowia. Asyndeza może być jednak zinterpretowana pozytywnie lub negatywnie. Pozytywnie - jako podsumowanie poprzedniego wersetu o błyskawicy w Mt 24,27 (sępy pełniłyby tę samą retoryczną funkcję co błyskawica). Negatywnie - jako przestroga przed pojawieniem się fałszywych proroków - „sępów” - którzy wykorzystując oczekiwanie na paruzję, wskazują konkretny czas i miejsce, gdzie ma ona nastąpić, i w ten sposób wprowadzają wspólnotę wierzących w błąd (Mt 24,24: „powstaną bowiem fałszywi mesjasze i fałszywi prorocy...”). W przepowiadaniu fałszywych proroków uniwersalny charakter paruzji zostałby ograniczony do lokalnego wydarzenia, zarezerwowanego dla wtajemniczonych (,tam, gdzie”). Choć obie interpretacje (pozytywna i negatywna) są możliwe, nie można egzegetycznie wykazać, która z nich jest bardziej prawdopodobna i odpowiada zamysłowi ewangelisty. Jednak ogólny wydźwięk całej perykopy Mt 24,23-28 odpowiadałby raczej pierwszej - pozytywnej interpretacji.

Niewykluczone, że przysłowie uwypukla również widzialność i uniwersalność paruzji: tak jak trudno nie zauważyć błyskawicy przecinającej widnokrąg, i jak trudno, by uwadze sępów umknęła obecność padliny ${ }^{67}$, tak paruzja stanie się namacalnym doświadczeniem całej ludzkości. Jej nadejście nie będzie przedmiotem ezoterycznej wiedzy zarezerwowanej dla nielicznych wtajemniczonych, jak chcieliby fałszywi prorocy (Mt 24,23-26). Choć taka interpretacja jest możliwa,

67 Tak sugeruje Ulrich Luz (Matthew 21-28. A Commentary [Hermeneia 61C; Minneapolis, MN: Fortress Press 2005] 199); zob. też Müller, „Velocemente e inevitabilmente”, 380; W.D. Davies D.C. Allison, The Gospel according to St. Matthew (ICC; Edinburgh: Clark 1997) III, 356. 
wydaje się, że w kontekście literackim ewangelista podkreśla raczej potrzebę zachowywania czujności wobec znaków (również fałszywych) zapowiadających niechybne nadejście paruzji w każdym możliwym miejscu.

\subsubsection{Q 17,37 jako przysłowie u Łukasza (Łk 17,37)}

Jeżeli u Mateusza związek przyczynowo-sprawczy między obecnością padliny a pojawieniem się sępów ułatwia zrozumienie logionu, to u Łukasza nie pomaga w sposób jednoznaczny ${ }^{68}$. Dzieje się tak, dlatego że u Mateusza bezpośredni kontekst współgra z logiką logionu (obraz błyskawicy pasuje do obrazu padliny i sępów, tak jak obraz fałszywych proroków można połączyć z obrazem sępów). U Łukasza z kolei związek logionu z kontekstem jest problematyczny i może być interpretowany dwojako: a) logion odcina się od kontekstu; lub b) pozostaje z nim związany.

a) Odcinając się od kontekstu, logion może być rodzajem wybiegu, by nie udzielić odpowiedzi na pytanie uczniów: „gdzie?” - bo nie to powinno ich interesować, kiedy oczekują paruzji. Treść logionu nie miałaby więc żadnego znaczenia i pozostawałaby zagadką ${ }^{69}$. Ale w jakim celu Jezus miałby uciekać się do tak osobliwego zabiegu, skoro $\mathrm{w}$ innym miejscu jasno wyraża dezaprobatę wobec ciekawości bądź niewłaściwych żądań uczniów (np. Dz 1,6-7; zob. też Mk 10,35-45)?

b) Jeśli treść logionu jest związana z kontekstem, niewykluczone, że i tutaj związek przyczynowo-sprawczy między padliną a sępami został wykorzystany. Jak padlina nie ukryje się przed wzrokiem sępów, tak wydarzenia zapowiadające paruzję nie pozostaną niezauważone przez wierzących ${ }^{70}$, którzy „mają oczy, by widzieć”, i „uszy, by słyszeć”. Sami uczniowie, mając wiarę, dostrzegą znaki nadchodzącej paruzji. „Tam, gdzie ciało, tam i się sępy zgromadzą” oznaczałoby „spostrzegawczy/wierzący dostrzeże wszystko, co trzeba”.

Jeśli interpretacja jest właściwa, krótsza mowa eschatologiczna (Łk 17,20-37; zob. też wyżej § 3.1.2) zaczynałaby się i kończyła motywem dostrzegalności/niedostrzegalności królestwa Bożego/paruzji i tym samym byłaby wpisana w inkluzję. Na początku rzeczywiście pojawia się problem, czy królestwo Boże przyjdzie w sposób dostrzegalny ( $\mu \varepsilon \tau \grave{\alpha} \pi \alpha \rho \alpha \tau \eta \rho \dot{\sigma \varepsilon \omega \varsigma ~-~ Ł k ~ 17,20), ~ a ~ z a r a z ~ p o t e m ~ s ł y s z y-~}$

68 O roli kontekstu w doprecyzowaniu znaczenia logionu Q 17,37, słusznie pisze John Nolland (The Gospel of Matthew, 981): „Only the context allows the application of the bizarre metaphor to be determined; and even then it has spawned many explanations".

69 W tym kluczu Bovon, Luke, II, 525. Coś podobnego sugeruje Franciszek Mickiewicz (Ewangelia wedlug świętego Łukasza, 249), lecz dodaje, że „nie ma sensu pytać, gdzie objawi się Chrystus i gdzie się dokona sąd eschatologiczny, ponieważ będzie on miał charakter uniwersalny".

70 W tym kierunku idzie Joseph A. Fitzmyer (The Gospel According to Luke X-XXIV. A New Translation with Introduction and Commentary [AB 28A; Garden City, NY: Doubleday 1985] 1173). 
my zapowiedź, że uczniowie, pomimo usilnego pragnienia, nie ujrza ani jednego

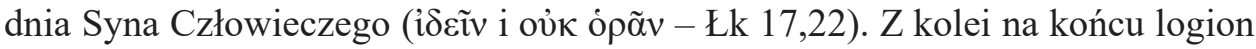
zapewniałby, że znaki nadchodzącej paruzji nie umkną spostrzegawczości ucznia (Łk 17,37b). Niezdrowa udręka i chorobliwe wytężanie wzroku wobec wydarzeń eschatycznych jest niepotrzebne (Łk 17,20-22). Wystarczy ufność i wiara w Jezusa, by znaki Jego bliskości stały się widoczne ${ }^{71}$. W takim znaczeniu logion Q 17,37 łączyłby się inkluzyjnie z początkiem mowy eschatologicznej, a jego powiązanie z kontekstem, bardziej wysublimowane retorycznie, byłoby nawet ściślejsze niż u Mateusza.

Inkluzja zbudowana na antytezie dwóch elementów („,niedostrzegalność królestwa [Łk 17,20a] - dostrzegalność znaków [Łk 17,37b])" uwypukla główny problem wspólnoty wierzącej: gdzie i jak ,zlokalizować” królestwo Boże wraz z nadchodzącą paruzją ( Łk 17,20b-37a)? Ale jednocześnie sugeruje teologiczne rozwiązanie tego problemu. Otóż, jeśli w czasie poprzedzającym paruzję królestwo Boże nie będzie dostrzegalne w swej eschatycznej pełni (pierwszy element: „niedostrzegalność”), sama paruzja zostanie poprzedzona znakami, które uczeń dostrzeże w wierze i rozpozna (drugi element: „dostrzegalność”). Z kolei nieokreśloność czasowo-przestrzenna logionu Q 17,37 (zob. wyżej analiza składni $\mathrm{w} \S 2.1$ ) podpowiada, że przygotowanie do paruzji to nie kwestia namierzenia jej geograficznej lokalizacji, lecz wydarzenie wszechobecne, dotykające ludzkości w jej codzienności, gdziekolwiek się znajduje ${ }^{72}$. Ponadto, jeśli Jezus „lokalizu-

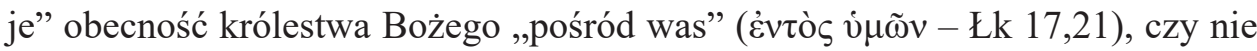
oznacza to, że znaki nadchodzącej paruzji powinny być poddane wewnątrzeklezjalnemu rozpoznaniu? Czyż Kościół nie jest zaczynem królestwa Bożego na ziemi? i oczekiwanie na powtórne przyjście Jezusa nie powinno być przeżywane wspólnotowo, na wzór Maryi i Apostołów, którzy „na tym samym miejscu” (غ́лì

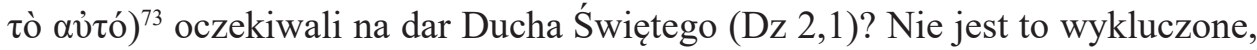
jeśli weźmiemy pod uwagę eklezjalną wrażliwość św. Łukasza.

Widzialność znaków (,sami zobaczycie”), powszechność (,gdziekolwiek jesteście”) i eklezjalne rozpoznanie (,pośród was”) to cechy właściwej postawy

71 Problem wiary i ufnej modlitwy pojawia się zaraz po przysłowiu o padlinie i sępach w Łk 18,1-8.

72 Tak J. Zmijewski, Die Eschatologiereden des Lukas Evangeliums. Eine traditions- und redaktionsgeschichtliche Untersuchung zu Lk 21,5-36 und Lk 17,20-37 (BBB 40; Bonn: Hanstein 1972) 506-518. Z jego interpretacją polemizuje Topel („What Kind of a Sign Are Vultures?”, 407-410), twierdząc, że nie chodzi o miejsce paruzji (,gdziekolwiek”), ale o ogólnie pojętą czasoprzestrzeń człowieka (,kiedykolwiek"), dlatego pytanie uczniów o miejsce jest niewłaściwe, ponieważ rozpoznają paruzję, dopiero wtedy, gdy ona nastąpi - post factum - tak jak sępy po śmierci zwierzęcia rozpoznają obecność martwego ciała. Interpretację Josefa Zmijewskiego z uwypukleniem powszechności paruzji (dotykającej każdego) wydają się popierać niektórzy egzegeci cytowani przez Mickiewicza (Ewangelia wedhug świętego Łukasza, 249).

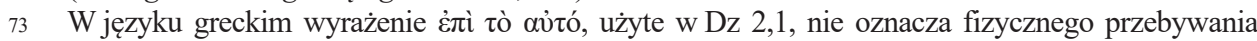
w jednym miejscu, jak sugeruje BT V, lecz raczej jednomyślność i duchową więź, jaka łączy członków Kościoła w Jezusie Zmartwychwstałym. 
ucznia wobec nadchodzącej paruzji. Logion Q 17,37 u Łukasza pełniłby więc funkcję przysłowia o spostrzegawczości i wpisywałby się w swój kanoniczny i teologiczny kontekst.

\subsubsection{Końcowy wniosek}

Przysłowie wyrażające ponadczasową prawdę jest konserwatywne w formie i treści. Często przemyca archaizmy i przechowując wielowiekową mądrość, jest zrozumiałe dla kolejnych pokoleń. Jeśli logion Q 17,37 jest przysłowiem w dwóch wersjach, powinien odpowiadać tym podstawowym kryteriom. Owszem widać różnice w formie, ale można je wytłumaczyć tym, że Mateusz i Łukasz - niezależnie od siebie - próbują przetłumaczyć na język grecki semicką frazę. I robią to - jak widzieliśmy - każdy na swój sposób (zob. § 2.3.2). Jednak co do treści i zrozumienia logionu, powinna panować między nimi całkowita zgoda. Tak się jednak nie dzieje. Logion Q 17,37 u Mateusza jest przestrogą przed gwałtownością eschatycznych wydarzeń i wezwaniem ucznia, by dostrzegając znaki nadchodzącego przełomu, odpowiednio się przygotował i nie był zaskoczony. Natomiast u Łukasza akcent pada nie tyle na gwałtowność i nieuchronność paruzji, ile na potrzebę spostrzegawczości i właściwe rozpoznanie znaków, które wskazują, że królestwo Boże już jest obecne i dynamicznie rozwija się ku eschatycznej pełni. Mateusz przestrzega bardziej w duchu starotestamentalnego proroctwa. Łukasz dodaje otuchy, uwypuklając, jak dostrzec na eschatologicznym horyzoncie słów Jezusa Ewangelię - Dobrą Nowinę. Fakt, że nie ma dokładnej zbieżności między Mateuszem i Łukaszem w jednoznacznym zrozumieniu logionu ${ }^{74}$, sugerowałby, że: a) logion nie jest przysłowiem; albo b) jeden z ewangelistów (prawdopodobnie Łukasz, który był prozelitą) nie znał jego pierwotnego semickiego znaczenia i zinterpretował go na swój sposób. Warto też odnotować, że zrozumienie logionu Q 17,37 jako przysłowia opierało się ściśle na analizie kontekstu. U Mateusza ta analiza była o wiele prostsza, u Łukasza bardziej karkołomna i nieoczywista (stąd wątpliwość, czy przypadkiem nie jest nadinterpretacją).

Jeśli porównamy wydźwięk logionu Q 17,37 z innymi przysłowiami, jakie pojawiają się Ewangeliach („lekarzu ulecz samego siebie” [por. Łk 4,23], ,jeśli ślepy ślepego prowadzi, obaj w dół wpadną” [por. Mt 15,14], „kto mieczem wojuje, od miecza ginie” [por. Mt 26,52], „tylko wśród swoich prorok jest lekceważony" [por. Mt 13,57; Mk 6,4; Łk 4,24] itp.), nie ma pewności co do jego prowerbialnego charakteru. Dlatego zobaczmy trzecią możliwość: logion 17,37 nie byłby ani cytatem, ani przysłowiem, lecz znakiem.

74 Wskazaliśmy jeden punkt styczności między Mt a Łk w zrozumieniu Q 17,37. Jednak przez różnice w kontekstach nie wydaje się przekonywający (zob. wyżej § 3.2.1, trzeci akapit). 


\subsection{Logion $\mathrm{Q} 17,37$ jako znak (signum)}

Pojawienie się sępów wokół padliny byłoby znakiem na równi z obrazem drzewa figowego, którego gałęzie nabrzmiewają sokami, pokrywają się liśćmi i zapowiadają nadchodzące lato (Mt 24,32-33; Mk 13,28-29; Łk 21,29-31). Podobne motywy literackie są wykorzystywane w wielu kulturach. Wystarczy wspomnieć inwokację Lukrecjusza do Wenus, której przybycie zwiastują oznaki zbliżającej się wiosny:

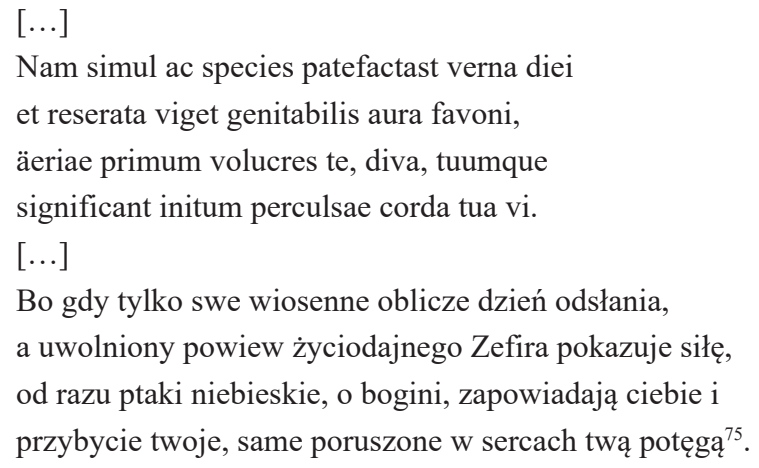

Zachowanie otaczającej przyrody zapowiada zmianę pory roku i usposobienia ludzi, ale może pełnić, w świetle późniejszych wydarzeń, także funkcję proroctwa, swoistego vaticinium ex eventibus, którego ludzie początkowo nie potrafili zrozumieć (zob. początek Ogniem i mieczem Henryka Sienkiewicza).

Padlina i gromadzące się wokół sępy to znak i zapowiedź śmierci wraz z towarzyszącym jej rozkładem i biologicznym unicestwieniem. Wyjaśnienie byłoby proste i oczywiste. Jednak czy pasuje do kontekstu mowy eschatologicznej, w której się znajduje?

\subsubsection{Q 17,37 jako znak u Mateusza (Mt 24,28)}

U Mateusza uczniowie pytają, jaki będzie znak ( i końca świata (Mt 24,3). W odpowiedzi Jezus kreśli obraz teraźniejszości Kościoła, w którym pośród zła, wojen i zgorszenia, głoszona jest Ewangelia o królestwie. Logion Q 17,37 byłby krótkim podsumowaniem całego opisu (Mt 24,4-27), a obraz w nim zawarty - znakiem kulminacyjnego momentu - ucisku ( $\theta \lambda \tilde{i} \psi 1 \varsigma)$,

75 Lucretius, De rerum natura I, 10-13 (red. J. Henderson) (LCL 181; Cambridge, MA - London: Harvard University Press 1924) 2-3; thumaczenie dosłowne - własne. Podobnie Wirgiliusz opisuje rolników umiejących odczytać w zachowaniu przyrody znaki Jowisza: Virgil, Georgics I, 351-355 (ale też I, 461-488) (red. J. Henderson) (LCL 63; Cambridge, MA - London: Harvard University Press 1999) 125, 130-133. 
po którym natychmiast ( $\varepsilon \dot{\theta} \theta \dot{c} \omega \varsigma$ - Mt 24,29), kiedy już wszystko ma pogrążyć się w cmentarnej ciszy, znacząc zwycięstwo zła i śmierci, ukazuje się znak ( Syna Człowieczego. Przy takiej lekturze uderza antytetyczne zestawienie dwóch znaków - złego i dobrego - oddalonych od siebie jedynie trzema wersetami: znak złowróżbny - zapowiadający śmierć (Mt 24,28) - i znak pozytywny - zapowiadający nadejście Syna Człowieczego (Mt 24,32-33). Obecność sępów to znak, że nie ma już żadnej nadziei, wszystko przepadło i pozostaje poddać się nieuchronnemu procesowi rozkładu. Ale właśnie w najmroczniejszej godzinie, kiedy wszystko wydawało się przesądzone, pojawia się znak Syna Człowieczego, zmartwychwstałego i uwielbionego Pana, który jako eschatologiczny sędzia przychodzi, by dokonać sądu nad złem i śmiercią. To zestawienie dwóch znaków uwypukla plastycznie, w kim należy pokładać nadzieję i szukać zbawienia.

\subsubsection{Q 17,37 jako znak u Łukasza $(Ł k 17,37)$}

U Łukasza obraz ciała/padliny i sępów może być rozumiany jako znak śmierci i rozkładu, ale nie jako rzeczywistości, która zagraża człowiekowi niejako z zewnątrz, wzbudzając w nim pragnienie wybawienia (jak u Mateusza), lecz bardziej jako obraz sytuacji egzystencjalnej, w którą człowiek jest istotowo uwikłany, bez względu na to, gdzie się znajduje i do jakiego pokolenia należy: tych, którzy są ,żywi i pozostawieni ( $\pi \varepsilon \rho \imath \lambda \varepsilon \imath \pi$ ó $\mu \varepsilon v o r)$ na przyjście Pana” (1Tes 4,15), czy tych, którzy już pomarli (1Tes 4,15-16). Między nimi (,,wzięci-zostawieni”) nie ma różnicy, bo doświadczenie przemijania, kruchości i śmiertelności jest wspólne wszystkim. W takim rozumieniu odpowiedź Jezusa na pytanie, gdzie ludzie zostaną wzięci bądź zostawieni (Łk 17,34-37), oznaczałaby, że losem każdego człowieka, na jakimkolwiek etapie jego życia i rozwoju, w jakiejkolwiek epoce historycznej, jest śmierć i biologiczne unicestwienie („tam, gdzie ciało i sępy”). Człowiek ma wobec tego dwie możliwości: zbuntować się przeciw temu lub to zaakceptować. Każda z nich przynosi inny skutek: „kto będzie się starał zachować swoje życie, straci je; a kto je straci, zachowa je" (Łk 17,33). Bunt wobec własnej śmiertelności okazuje się bezskuteczny, natomiast akceptacja swej egzystencjalnej kruchości i znikomości otwiera perspektywę nadziei. W krótszej mowie eschatologicznej (Łk 17,26-37) widać egzystencjalny dramat człowieka wewnętrznie rozdartego, dla którego moment śmierci jest jednocześnie dniem Syna Człowieczego i czasem podjęcia ostatecznej decyzji, dniem kiedy decyduje się jego eschatologiczna przyszłość.

Jeśli uznanie całkowitej zależności od Boga wraz z postawą dziecięcej ufności i bezbronności jest znakiem otwarcia się na królestwo Boże, które przychodzi w osobie Syna Człowieczego, to chwilą ,sprawdzam”, kiedy człowiek w sposób pełny i ostateczny może pogodzić się ze swą kruchością i bezbronnością, jest właśnie moment śmierci. Postawa wobec własnej śmierci jest tym, co wyróż- 
nia ucznia Jezusa. W śmierci uczeń oddaje się całkowicie Bogu, powierza $\mathrm{Mu}$ swe życie i ufnie wchodzi w otwarte ramiona kochającego Ojca. Nie ma sensu oglądać się za siebie („nie schodźcie z dachu”/,zostańcie na polu”/,pamiętajcie o żonie Lota" Łk 17,31-32). Miejsce, ,gdzie jest ciało, tam i zgromadzą się sępy” to jednocześnie miejsce śmierci i naszego zbawienia.

\subsubsection{Końcowy wniosek}

Według Mateusza obraz zawarty w logionie Q 17,37 jest znakiem nadchodzącej śmierci, która stanowi ostatni akt dramatu poprzedzającego paruzję, zarówno na poziomie życia osobistego i eklezjalnego, jak i w sensie uniwersalnym, obejmującego całą ludzkość. Jednoczesne ukazanie się znaku Syna Człowieczego zapowiada zbliżające się wybawienie i daje wierzącym pewność, że śmierć nie będzie ostatnim słowem eschatycznych wydarzeń.

U Łukasza obraz ciała/padliny i sępów jest znakiem egzystencjalnej znikomości, od której nie ma ucieczki. Jednak uczeń, przez akceptację swej egzystencjalnej kruchości, oddaje się ufnie Bogu, który ma moc wyprowadzić ze śmierci nowe życie. Ten obraz przywodzi na myśl postać św. Franciszka z Asyżu, który kiedy tracił wzrok i znajdował się u progu śmierci - potrafił w Pochwale stworzenia wyrazić entuzjastyczną przynależność do stworzonego świata. Zachwyt wobec wspaniałości wszechświata to chrześcijańska afirmacja dobra wszystkich rzeczy, jakie wyszły spod ręki Boga. Fraternizując z materialną rzeczywistością, Franciszek doświadczał ojcostwa Boga i nazywał nawet najmniejsze rzeczy braćmi i siostrami, bo wiedział, że wszystkie rzeczy, tak jak on, mają swe źródło w Bogu. Również śmierć widział jako nierozłączną towarzyszkę życia: pożegnania i choroby, cierpienie i rozczarowania, przymusowa rozłąka, miłosne zawody, zawodowe porażki, wszystkie nieprzewidziane tragedie są znakami ostrzegawczymi, zwiastującymi śmierć, która wcześniej czy później nadejdzie. Śmierć, pozostając niezgłębioną tajemnicą, jest dla niego siostrą (,sorella morte”), stałym domownikiem i bliskim krewnym. Nie jest efektem jakiejś tragicznej gry. Nie jest skutkiem jakiegoś hazardu. Nie jest wynikiem nieuchronnego fatum, któremu trzeba stawić czoła na zimno albo pogrążyć się w nieukojonej rozpaczy. Śmierć chrześcijanina można zrozumieć tylko w odniesieniu do śmierci Jezusa. Nieprzypadkowo Łukasz w krótszej mowie eschatologicznej przypomina o odrzuceniu i śmierci Jezusa (Łk 17,25). Innymi słowy, śmierć dla chrześcijanina jest zwycięstwem, które w oczach świata przybiera formę porażki i wielkiej przegranej. Podobnie jak śmierć Jezusa.

Warto też odnotować, że znak może odnosić się do trzech czasów: do przeszłości (jako ślad/poszlaka, np. trop zostawiony przez zwierzę), teraźniejszości (jako symptom rozwijającego się procesu, np. choroby) i przyszłości (jako sygnał do działania wobec nadchodzących wydarzeń, np. syrena przeciwlotnicza). 
Trop, symptom i sygnał - trzy funkcje znaku w zależności od jego czasowego odniesienia. Znajdują one potwierdzenie u starożytnych. Cyceron opisuje naturę znaku w następujący sposób:

Signum est, quod sub sensum aliquem cadit et quiddam significat, quod est ipso profectum videtur, quod aut ante fuerit aut in ipso negotio aut post sit consecutum et tamen indiget testimonii et gravioris confirmationis, ut cruor, fuga, pallor, pulvis, et quae his sunt similia.

Znak podpada pod jakiś zmysł i oznacza pewną rzecz, która wydaje się wychodzić z niego, i albo była wcześniej albo w tym samym czasie albo pojawiała się później. Wymaga jednak dowodu i wiarygodnego potwierdzenia, np. krwi, ucieczki, bladości, prochu i tym podobnych ${ }^{76}$.

Św. Augustyn, opierając się na Cyceronie, doprecyzowuje:

Signum est $[\ldots]$ res, praeter speciem quam ingerit sensibus, aliud aliquid ex se faciens cogitationem venire: sicut vestigio viso, transisse animal cuius vestigium est, cogitamus; et fumo viso, ignem subesse cognoscimus; et voce animantis audita, affectionem animi eius advertimus, et tuba sonante milites vel progredi se vel regredi, et si quid aliud pugna postulat, oportere noverunt.

Znak jest [...] rzeczą, która poza swym wyglądem, jaki dosięga zmysły, przywodzi na myśl coś innego; tak jak zobaczywszy trop, myślimy, że przeszło tamtędy zwierzę, do którego należą ślady; albo zobaczywszy dym, poznajemy, że gdzieś tam kryje się ogień; albo usłyszawszy głos jakiejś osoby, czujemy, jakie jest jej usposobienie; albo słysząc odgłos trąbki, żołnierze wiedzą, czy mają atakować, czy się wycofać, albo zrobić coś innego, czego wymaga walka ${ }^{77}$.

Jeśli Q 17,37 jest znakiem, to u obu ewangelistów odnosi się do przyszłości, wzywając do podjęcia odpowiednich decyzji i działań, które mają początek w rozpoznaniu (Mt 24,30-36) bądź przyjęciu (Łk 17,24-25) znaku Syna Człowieczego. Jeśli u Mateusza zrozumienie znaku Syna Człowieczego jako nadchodzącego sądu wymaga spostrzegawczości i kontemplacji dzieła stworzenia (klucz mądrościowy), to u Łukasza staje się ono akceptacją życia na wzór Syna Człowieczego, „który musi wiele wycierpieć i być odrzuconym przez to pokolenie" (klucz egzystencjalny). Dlatego u Łukasza dostrzega się zawarty w znaku element teraźniejszości, który wyróżnia ludzką egzystencję Jezusowego ucznia. Znak padliny i sępów staje się wezwaniem do złożenia świadectwa wiary wobec

76 Cicero, De inventione I, 48 (red. J. Henderson) (LCL 386; Cambridge, MA - London: Harvard University Press 1949) 86-87; thumaczenie własne.

77 Augustinus, De doctrina christiana II, 1,5 (red. J. Martin - K.D. Daur) (CCSL 32; Turnhout: Brepols 1962) 1-167; thumaczenie własne. 
śmierci i przemijania (zob. wyżej § 3.3.2). Wydaje się, że Łukasz istotnie (biorąc pod uwagę całą jego teologię) zwraca bardziej uwagę na teraźniejszość znaku, która przygotowuje eschatologiczną przyszłość. U Mateusza, w paralelnym fragmencie, nie jest to aż tak zauważalne, choć w niektórych przypowieściach również wydaje się on podkreślać rolę teraźniejszości determinującej eschatologiczną przyszłość ucznia.

Niewykluczone, że w znaku padliny i sępów mamy również zawoalowaną krytykę wróżbiarstwa, z którym świat grecko-rzymski łączył obecność i zachowanie ptaków (zob. wyżej § 2.2.1.3). Ptaki-sępy nie są posłańcami pogańskich bogów czy nieujarzmionych przez człowieka sił przyrody, którym należy oddawać cześć boską, lecz wpisane są w dzieło stworzenia, swym istnieniem i sposobem bytowania kierują wzrok ucznia z ziemskiej doczesności, naznaczonej śmiercią, ku jedynemu Bogu - Stwórcy i Zbawcy człowieka.

\section{Zakończenie}

Analiza egzegetyczna logionu Q 17,37 u Mateusza i Łukasza wraz z próbą rekonstrukcji semickiego oryginału nie rozstrzyga jednoznacznie, które $\mathrm{z}$ trzech zaproponowanych wyjaśnień (cytat, przysłowie, znak) odpowiada zamysłowi ewangelistów. Widać jednak, że każdy z nich - choć umiejscawia go w kontekście mowy eschatologicznej Jezusa - nadaje mu inny odcień znaczeniowy. Różnice w interpretacji wykluczałyby więc zrozumienie go jako przysłowia $\mathrm{i}$ tym samym należałoby odrzucić klasyczną interpretację, jaka utrwaliła się we współczesnej egzegezie Mt 24,28 i Łk 17,37c. Przysłowie z natury powinno zachować swe uniwersalne znaczenie bez względu na kontekst, w jakim się znajduje. Skoro tak się nie dzieje, jest bardziej prawdopodobne, że logion Q 17,37 pełnił w źródle Q bądź funkcję cytatu-odnośnika do Hi 39,30, bądź znaku śmierci, i odpowiednio w takim charakterze został wykorzystany przez synoptyków.

Warto odnotować również, że badanie logionu Q w kontekście literacko-teologicznym odsłania jego wyjątkowo elastyczną zdolność akomodacyjną i semantyczną, która raz uwypukla jeden aspekt mowy eschatologicznej, innym razem drugi. To może sugerować, że sami ewangeliści mieli problem z jego zrozumieniem, ale włączając go do kanonicznego kontekstu, przekazali zagadkową wypowiedź Jezusa z określonym znaczeniem, która tak czy inaczej mogłaby być też odebrana przez czytelnika nie tylko jako swoiste memento mori, ale i ostrzeżenie przed śmiercią wieczną, jako przypomnienie o robaku, który nigdy nie sczeźnie (Mk 9,48). 


\section{Bibliografia}

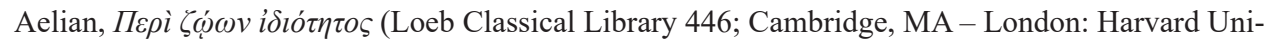
versity Press 1958).

Ambrosius, Expositio evangelii secundum Lucam (red. M. Adriaen) (Corpus Christianum Series Latina 14; Turnhout: Brepols 1957) 1-400.

Ambroży, Wykład Ewangelii wedtug św. Łukasza (red. A. Bogucki; tł. W. Szołdrski) (Pisma Starochrześcijańskich Pisarzy 16; Warszawa: ATK 1977).

Appolinaris, „Fragmenta in Matthaeum (in catenis)”, Matthäus-Kommentare aus der griechischen Kirche (red. J. Reuss) (Texte und Untersuchungen 61; Berlin: Akademie-Verlag 1957) 1-45.

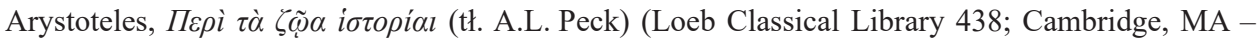
London: Harvard University Press 1970) II.

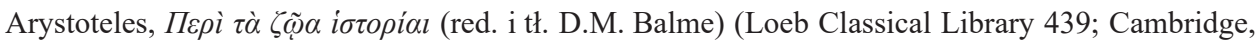
MA - London: Harvard University Press 1991) III.

Arystoteles, O duszy. Krótkie rozprawy psychologiczno-biologiczne. Zoologia. O częściach zwierząt (tł. P. Siwek) (Dzieła Wszystkie 3; Warszawa: PWN 1992).

Augustyn, De doctrina christiana (red. J. Martin) (Corpus Christianorum Series Latina 32; Turnhout: Brepols 1962).

Beda Venerabilis, In Lucae evangelium expositio (red. E. Dekkers) (Clavis Patrum Latinorum; Turnhout: Brepols 1995).

Black, M., „The Aramaic Document in Q with Notes on Luke 17.22, Matthew 24.26 (Luke 17.23)”, Journal for the Study of the New Testament 40 (1990) 33-41.

Blass, F. - Debrunner, A., Grammatica del greco del Nuovo Testamento, wyd. 2 (Introduzione allo studio della Bibbia. Supplementi 2; Brescia: Paideia 1997).

Bovon, F., Luke. I. A Commentary on the Gospel of Luke 1:1-9:50 (Hermeneia 63A; Minneapolis, MN: Fortress Press 2002).

Bovon, F., Luke. II. A Commentary on the Gospel of Luke 9:51-19,27 (Hermeneia 63A; Minneapolis, MN: Fortress Press 2013).

Brown, S., „The Matthean Apocalypse”, Journal for the Study of the New Testament 4 (1979) 2-27.

Cicero, De divinatione (red. J. Henderson) (Loeb Classical Library 154; Cambridge, MA - London: Harvard University Press 1923).

Cicero, De inventione (red. J. Henderson) (Loeb Classical Library 386; Cambridge, MA - London: Harvard University Press 1949).

Cyrillus Alexandrinus, Commentarii in Matthaeum Matthäus-Kommentare aus der griechischen Kirche (red. J. Reuss) (Texte und Untersuchungen 61; Berlin: Akademie-Verlag 1957) 153-269.

Dalman, G., „The Hebrew New Testament of Franz Delitzsch”, The Old and New Testament Student 15/3-4 (1892) 145-150.

Davies, W.D. - Allison, D.C., The Gospel according to St. Matthew (International Critical Commentary; Edinburgh: Clark 1988-1997) I-III.

Elian Klaudiusz, $O$ właściwościach zwierząt (tł. A.M. Komornicka) (Warszawa: Prószyński i S-ka 2005).

Ehrhardt, A.A.T., „Greek Proverbs in the Gospel”, Harvard Theological Review 46 (1953) 68-72.

Euthymius Zigabenus, Commentarius in quatuor evangelia (PG 129,9-1502). 
Fitzmyer, J.A, The Gospel According to Luke X-XXIV. A New Translation with Introduction and Commentary (AB 28A; Garden City, NY: Doubleday 1985).

Gilbert, M., La sapienza del cielo (Milano: Edizioni San Paolo 2005).

Golias, M., Gramatyka grecka, wyd. 4 (Warszawa: PWN 1985).

Guenther, H.O., „When 'Eagles’ Draw Together”, Forum 5 (1989) 140-150.

Heinrici, C.F.G. (red.), Des Petrus von Laodicea Erklärung des Matthäusevangeliums (Beiträge zur Geschichte und Erklärung des Neuen Testamentes 5; Lipsk: Dürr 1908).

Helbing, R., Die Kasussyntax der Verba bei der Septuaginta. Ein Beitrag zur Hebraismenfrage und zur Syntax der Kovví (Göttingen: Vandenhoeck \& Ruprecht 1928).

Hieronymus, Commentarii in evangelium Matthaei (red. E. Dekkers) (Clavis Patrum Latinorum; Turnhout: Brepols 1995).

Hippolytus, „De antichristo”, Hippolyt's kleinere exegetische und homiletische Schriften (red. H. Achelis) (Die griechischen christlichen Schriftsteller 1/2; Leipzig: Hinrichs 1897) 1-47.

Hoffmann, P. - Kloppenborg, J.S. - Robinson, J.M. (red.), The Critical Edition of $Q$ (Hermeneia; Minneapolis, MN: Fortress Press 2008).

Homer, Iliad (red. J. Henderson) (Loeb Classical Library 170; Cambridge, MA - London: Harvard University Press 1924).

Homer, Odyssey (red. J. Henderson) (Loeb Classical Library 104; Cambridge, MA - London: Harvard University Press 1919).

Irenaeus Lugdunensis, Adversus haereses seu Detectio et eversio falso cognominatae Gnoseos (red. E. Dekkers) (Clavis Patrum Latinorum; Turnhout: Brepols 1995).

Jay, E.G., Grammatica greca del Nuovo Testamento (Casale Monferrato: Piemme 1993).

Joüon, P., Grammaire de l'hébreu biblique (Roma: PIB 1923).

Kloppenborg, J.S., The Formation of Q. Trajectories in Ancient Wisdom Collections (Studies in Antiquity and Christianity; Philadelphia, PA: Fortress Press 1987).

Koehler, L. - Baumgartner, W., The Hebrew and Aramaic Lexicon of the Old Testament (Leiden Boston, MA - Köln: Brill 2001) I-II.

Lang, T.J., „"Where the Body Is, There also the Eagles Will Be Gathered»: Luke 17:37 and the Arrest of Jesus", Biblical Interpretation 21/3 (2013) 320-340.

Leaney, A.R.C., Commentary on the Gospel according to St. Luke, wyd. 2 (Black's New Testament Commentaries; London: Black 1966).

Lucretius, De rerum natura (red. J. Henderson) (Loeb Classical Library 181; Cambridge, MA - London: Harvard University Press 1924).

Luz, U., Matthew 21-28. A Commentary (Hermeneia 61C; Minneapolis, MN: Fortress Press 2005). de Marchi, J., „Ubicumque fuerit corpus, ibi congregabuntur et aquilae”, Verbum Domini 18 (1938) 329-333.

Marcos, N.F., La Bibbia dei Settanta (Introduzione allo studio della Bibbia. Supplementi 6; Brescia: Paideia 2000).

Mickiewicz, F., Ewangelia według świętego Łukasza. Rozdziały 12-24 (Nowy Komentarz Biblijny. Nowy Testament 3/2; Częstochowa: Edycja Świętego Pawła 2012).

Monasterio, R.A. - Carmona, A.R., Vangeli sinottici e Atti degli Apostoli (Introduzione allo studio della Bibbia 6; Brescia: Paideia 1995).

Müller, P., „Velocemente e inevitabilmente - La carogna e gli avvoltoi (Q 17,37)”, Compendio delle parabole di Gesù (red. R. Zimmermann) (Brescia: Queriniana 2011) 376-382. 
Nolland, J., The Gospel of Matthew. A Commentary on the Greek Text (New International Greek Testament Commentary; Grand Rapids, MI: Eerdmans 2005).

Origenes, „Commentaritorium series in evangelium Matthaei”, Origenes Werke (red. E. Klostermann) (Die griechischen christlichen Schriftsteller 38/2; Leipzig: Teubner 1933) XI, 93-101.

Orygenes, Komentarz do Ewangelii św. Mateusza (tł. K. Augustyniak) (Kraków: WAM 2002).

Paciorek, A., Ewangelia wedtug świętego Mateusza. Rozdziały 14-28 (Nowy Komentarz Biblijny. Nowy Testament 1/2; Częstochowa: Edycja Świętego Pawła 2008).

Pliny, Natural History (red. J. Henderson) (Loeb Classical Library 353; Cambridge, MA - London: Harvard University Press 1983).

Pseudo-Hippolytus, „De consumatione mundi”, Hippolyt's kleinere exegetische und homiletische Schriften (red. H. Achelis) (Die griechischen christlichen Schriftsteller 1/2; Leipzig: Teubner 1897) 289-309.

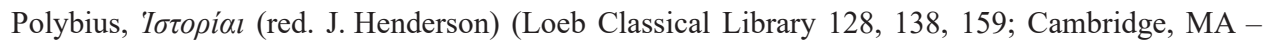
London: Harvard University Press 2010-2012) I, III-IV.

Rossé, G., Il Vangelo di Luca. Commento esegetico e teologico, wyd. 3 (Roma: Città Nuova 2001).

Scaiola, D., „La sapienza in Israele e nel Vicino Oriente antico”, Libri sapienziali e altri scritti (red. A. Bonora - M. Priotto) (Torino: Editrice Elledici 2005).

Speyer, W., „Geier”, Reallexikon für Antike und Christentum (Stuttgart: Hiersemann 1976) IX, 430-468.

Stöger, A., Vangelo secondo Luca, wyd. 4 (Commenti spirituali del Nuovo Testamento; Roma: Città Nuova 1994) I-II.

Thackeray, H.St.J., A Grammar of the Old Testament in Greek according to the Septuagint (Cambridge: Cambridge University Press 1909).

Thibaut, R., „Le Proverbe des vautours et du cadavre”, Nouvelle revue théologique 58 (1931) 57-58.

Topel, J., „What Kind of a Sign are Vultures? Luke 17,36b”, Biblica 84 (2003) 403-411.

Tov, E., „The Representation of the Causative Aspects of the Hiph 'il in the LXX. A Study in Translation Technique", Biblica 63 (1982) 417-424.

Tristram, H.B., The Fauna and Flora of Palestine (London: The Committee of the Palestine Exploration Fund 1884); przedruk (Cambridge - New York: Cambridge University Press 2013).

Virgil, Georgics (red. J. Henderson) (Loeb Classical Library 63; Cambridge, MA - London: Harvard University Press 1999).

Waltke, B.K. - O'Connor, M., An Introduction to Biblical Hebrew Syntax (Winiona Lake, IN: Eisenbrauns 1990).

Wettstein, J.J., Novum Testamentum Graecum (Amsterdam: Dommer 1751) I; przedruk (Graz: Akademische Druck- und Verlagsanstalt 1962) I.

Winniczuk, L., Ludzie, zwyczaje i obyczaje starożytnej Grecji i Rzymu, wyd. 4 (Warszawa: PWN 2008).

Zmijewski, J., Die Eschatologiereden des Lukas Evangeliums. Eine traditions- und redaktionsgeschichtliche Untersuchung zu Lk 21,5-36 und Lk 17,20-37 (Bonner biblische Beiträge 40; Bonn: Hanstein 1972).

Zuck, R.B., Basic Bible Interpretation. A Practical Guide to Discovering Biblical Truth (Colorado Springs, CO: Cook 1991). 